\title{
From terrestrial to shallow-marine depositional environments: reconstruction of the depositional environments during the Late Carboniferous transgression of the Lomfjorden Trough in NE Spitsbergen (Malte Brunfjellet Formation)
}

\author{
Christian Scheibner ${ }^{1}$, Dierk Blomeier ${ }^{2,3}$, Holger Forke ${ }^{3}$ \& Karin Gesierich ${ }^{1}$ \\ ${ }^{1}$ Bremen University, FB5, P.O. Box 330440, 28334 Bremen, Germany. \\ ${ }^{2}$ Norwegian Polar Institute, Fram Centre, 9296 Tromsø, Norway. \\ ${ }^{3}$ Millennia Stratigraphic Consultants, 35 Swansfield Lechlade, Glos. GL7 3SF, United Kingdom. \\ E-mail corresponding author (Christian Scheibner): scheibne@uni-bremen.de
}

\begin{abstract}
Sedimentary rocks of the Upper Carboniferous Malte Brunfjellet Formation are investigated in five sections, located on a N-S-oriented transect along the Lomfjorden Fault Zone in eastern Spitsbergen. Results of facies and microfacies analysis led to a redefinition of the Malte Brunfjellet Formation, and formerly unspecified Carboniferous sedimentary rocks in the investigated area are now assigned to this formation. In the northern part of the Lomfjorden Trough, the Malte Brunfjellet Formation consists of a $41 \mathrm{~m}$-thick, cyclic succession with variegated shales at the base and tidal flat sandstones or dolomites at the top. They are conformably deposited on gray, siliciclastic deposits of the Billefjorden Group, and in turn conformably overlain by the limestone succession of the Wordiekammen Formation. The cyclicity and overall sedimentary development of the mixed clastic/ carbonate succession indicate coastal plain to sabkha environments controlled by high-frequency sea-level fluctuations. In the southern Lomfjorden Trough, the Malte Brunfjellet strata, resting unconformably on Neoproterozoic basement rocks, comprise a basal, $13 \mathrm{~m}$-thick, siliciclastic interbedding of distinct red shales, siltstones and sandstones, reflecting alluvial to fluvial environments under warm, semi-arid climatic conditions. The redbed succession is separated by a $32 \mathrm{~m}$-thick scree-covered interval from a $15 \mathrm{~m}$-thick, cyclic intercalation of grayish sandstones, caliche horizons, and shallow-marine, near-shore limestones, forming the upper part of the formation. The deposits reflect a development into a coastal plain controlled by sea-level fluctuations and an overall rising sea level. This lateral facies variation with shallow-marine environments in the north and alluvial to near-shore environments in the south reflect a successive transgression of the Lomfjorden Trough from northerly directions. Biostratigraphy of smaller foraminfers and cyclostratigraphy indicate a Bashkirian age for the marine sediments deposited in the upper part of the Malte Brunfjellet Formation. The marine sediments in the Lomfjorden Trough are contemporaneous with shallow-marine deposits in the Billefjorden and the St. Jonsfjorden troughs in central and western Spitsbergen. They mark the first, nearly Spitsbergen-wide, transgression, which resulted in the Svalbardwide deposition of the shallow-marine carbonates of the Wordiekammen Formation.
\end{abstract}

Keywords: Late Carboniferous, Malte Brunfjellet Formation, alluvial, caliche, marine limestones, cyclostratigraphy, biostratigraphy, transgression, TR sequences

Received 18. February 2015 / Accepted 22. May 2015 / Published online 4. August 2015

\section{Introduction}

After the compressional forces of the Caledonian orogeny (Svalbardian Event; Stemmerik \& Worsley, 1989; Piepjohn et al., 2000; Worsley, 2008) ceased during the Early Carboniferous (Tournaisian), the clastic, non-marine strata of the Billefjorden Group (Tournaisian-Viséan) were deposited in a number of lowlands, which developed on top of the deposits of the Old Red Sandstone. The sediments, mainly consisting of fluvial to alluvial grayish sandstones and siltstones with

Scheibner, C., Blomeier, D., Forke, H. \& Gesierich, K. 2015: From terrestrial to shallow-marine depositional environments: Reconstruction of the depositional environments during the Late Carboniferous transgression of the Lomfjorden Trough in northeast Spitsbergen (Malte Brunfjellet Formation). Norwegian Journal of Geology 95, 127-152. http://dx.doi.org/10.17850/njg95-2-01.

(c) Copyright the authors.

This work is licensed under a Creative Commons Attribution 4.0 International License. 


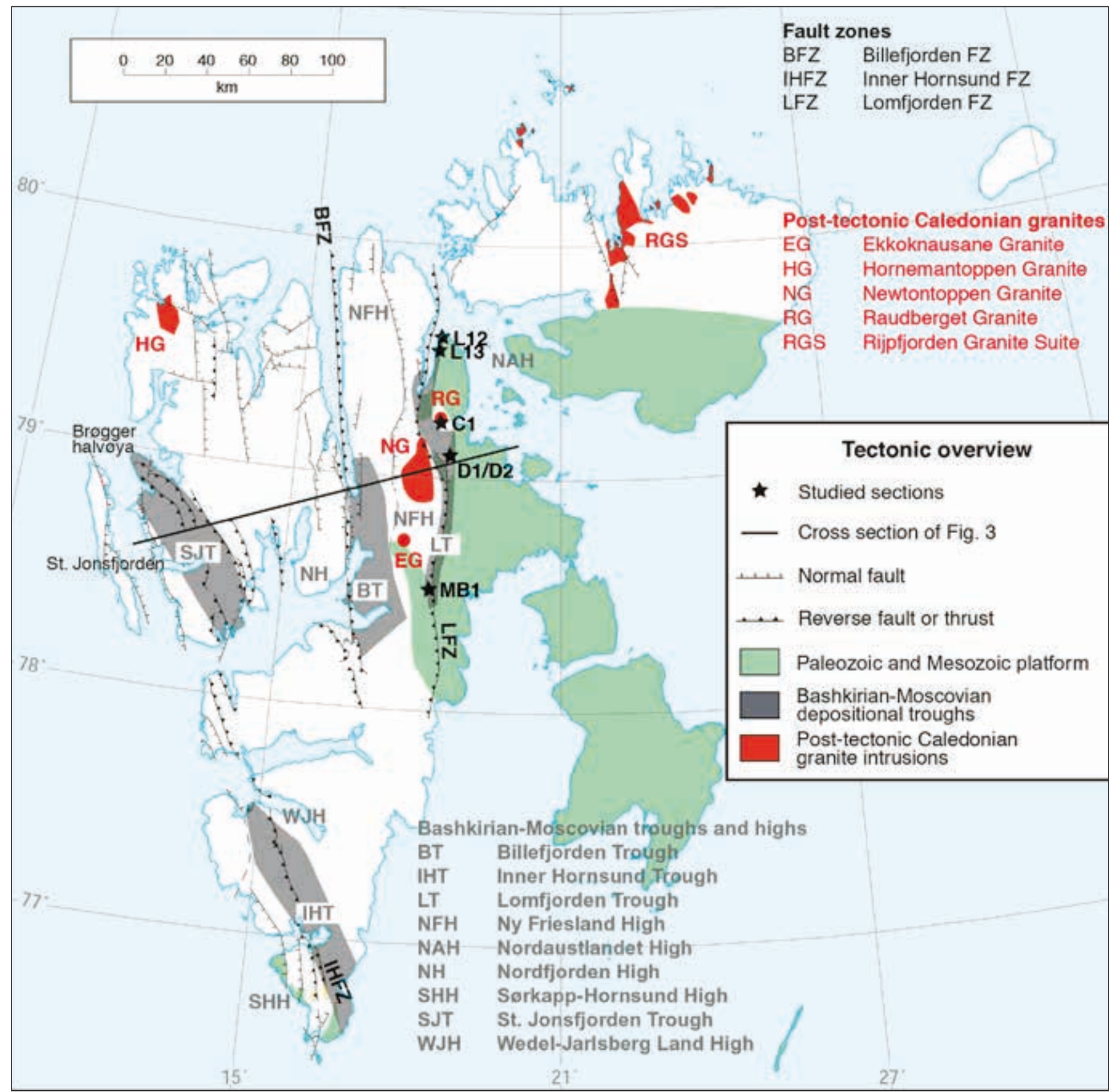

Figure 1. Structural geologic map of Svalbard showing the outcrop areas of the Carboniferous rift troughs and highs, major fault zones and Caledonian igneous rock exposures (modified from Dallmann et al., 2002).

minor conglomerates and shales (Steel \& Worsley, 1984; Worsley et al., 1986), were deposited under warm and humid climatic conditions, favoring the spread of lush wetland vegetation. The accumulation of organic plant material resulted in the local intercalation of coal seams (Billefjorden Trough, Bjørnøya; Figs. 1, 2; Gjelberg \& Steel, 1981; Stemmerik \& Worsley, 1989; Scheibner et al., 2012).

In the late Early Carboniferous (Serpukhovian), tectonic activity set in again, this time dominated by extensional forces due to active rifting. Rift valleys subsided along major, pre-existing fault zones (e.g., Billefjorden Fault
Zone, Lomfjorden Fault Zone; Fig. 1) and led to the development of a pronounced horst-and-graben mosaic. The latter was characterized by a series of roughly N-Strending, elongated, narrow rift troughs (St. Jonsfjorden Trough, Billefjorden Trough, Inner Hornsund Trough, Lomfjorden Trough) and adjacent highlands (Wedel Jarlsberg Land High, Ny-Friesland High, Nordfjorden High, Sørkapp-Hornsund High; Figs. 1, 2, 3; Stemmerik \& Worsley, 1989; Stemmerik, 2000).

A climatic change to overall drier climatic conditions at the end of the Early Carboniferous (Viséan) led to the collapse of the wetland ecosystems and is marked by 


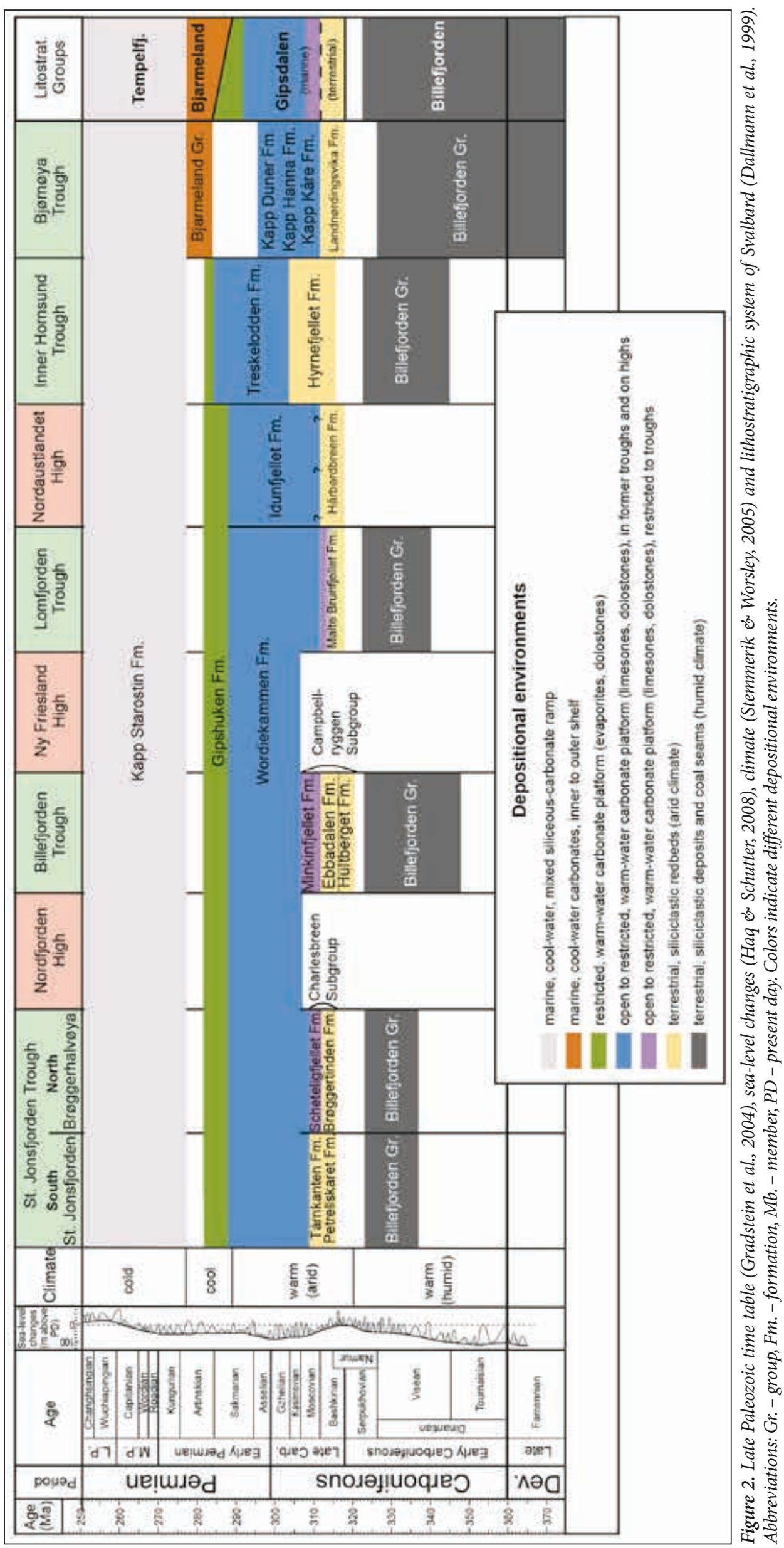




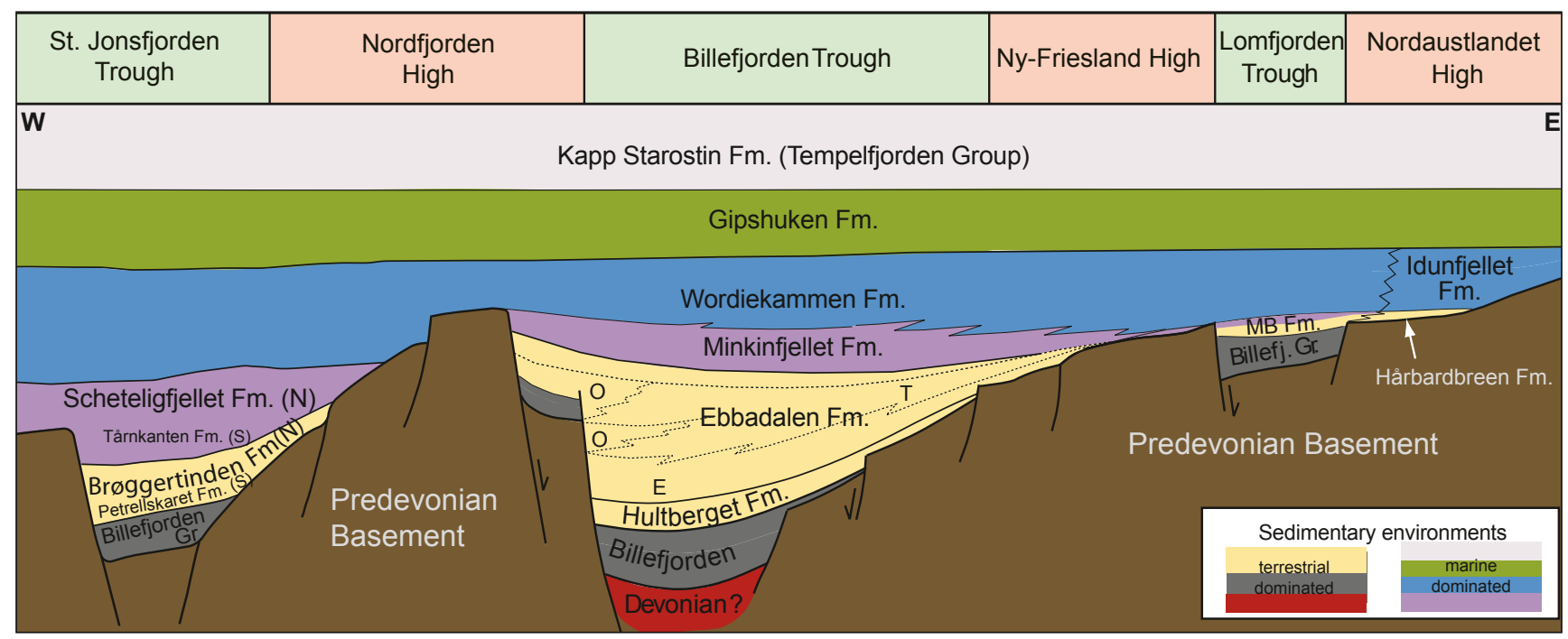

Figure 3. Schematic E-W-trending cross-section, showing the framework of the lithostratigraphic units across Spitsbergen's Late Paleozoic trough and highs. The positions of the formations in the St. Jonsfjorden Trough are indicated with N (north) and S (south). Abbreviations: O - Odellfjellet Member, T - Trikolorfjellet Member, E - Ebbaelva Member, MB Fm. - Malte Brunfjellet Formation.

the distinct and sharp boundary to the conformably(?) overlying Gipsdalen Group (Serpukhovian-Artinskian). Successions of siliciclastic red beds (conglomerates, sandstones, siltstones and shales), restricted to the individual troughs (Billefjorden Trough: Hultberget Formation; Lomfjorden Trough: Malte Brunfjellet and Hårbardbreen formations; St. Jonsfjorden Trough: Brøggertinden and Petrellskaret formations; Inner Hornsund Trough: Hyrnefjellet Formation; and Bjørnøya: Landnørdingsvika Formation; Figs. 2, 3) reflect semi-arid steppe- to desert-like environments.

The terrestrial setting prevailed until the beginning of the Late Carboniferous (Bashkirian) when globally rising sea levels caused a major marine transgression and the gradual submergence of most of Svalbard's land areas (Johannessen \& Steel, 1992; Hüneke et al., 2001). In the process, the lowlands of the troughs were successively flooded. Under a warm and dry climate, coastal sabkhas and tidal flats formed and terrestrial sediments were gradually replaced by marginal marine deposits, such as carbonates (dolostones, limestones) and evaporites (gypsum, anhydrite). The first marine ingressions are recorded during this time interval in the St. Jonsfjorden Trough (Brøggertinden Formation) and Billefjorden Trough (Ebbadalen Formation), and subsequently shallow-marine sediments dominated the individual troughs (St. Jonsfjorden Trough: Scheteligfjellet Formation; Billefjorden Trough: Minkinfjellet Formation; Figs. 2, 3).

By Moscovian times, active rifting ceased and the entire depositional area was progressively subsiding, resulting in the flooding of most of the remaining highs (apart from the Sørkapp-Hornsund High). Until the end of the Carboniferous, a thick succession of fossiliferous, shallow-marine limestones (Wordiekammen Formation) accumulated on a stable, shallow-marine, warm-water shelf (Figs. 2, 3; Pickard et al., 1996; Blomeier et al., 2009). Glacio-eustatic sea-level fluctuations, superimposed on the global, long-term sea-level rise, resulted in a pronounced cyclicity of the strata (Fig. 2).

In this manuscript, so far unspecified, Late Carboniferous deposits are assigned to the Malte Brunfjellet Formation, resulting in an extension/enhancement of the current formation definition. Based on the data, a paleogeographic reconstruction of one of Svalbard's Late Paleozoic sedimentary basins is presented, based on bio- and cyclostratigraphic architecture and detailed facies analyses of the strata. The present manuscript sets the Late Carboniferous depositional history of the Lomfjorden Trough into the current regional lithostratigraphic framework. We present new sedimentological and biostratigraphical data from five sections located within the Lomfjorden Trough, and correlate its depositional history to the other, wellknown, Late Carboniferous basins of Spitsbergen (St. Jonsfjorden Trough, Billefjorden Trough).

\section{Late Paleozoic sea-level history}

The Late Paleozoic is characterized by periodic glaciations of southern Gondwana, which resulted in high-frequency sea-level fluctuations of more than 100 m amplitude (Soreghan \& Giles, 1999; Golonka \& Ford, 2000; Joachimski et al., 2006). These sea-level changes led to a pronounced cyclicity of the marine strata worldwide (Ross \& Ross, 1985).

In central Spitsbergen, four long-term transgressiveregressive (TR) cycles, each lasting about 12 to 18 million 
years, have been interpreted from Late Carboniferous to Early Permian strata (Fig. 4; Samuelsberg \& Pickard, 1999). The two older TR cycles cover the time interval of this study and are presented in more detail. In central Spitsbergen (Billefjorden Trough) the lower, transgressive part of the first cycle comprises the upper Serpukhovian Hultberget Formation and the lower Bashkirian Ebbaelva Member of the overlying Ebbadalen Formation, while the upper, regressive part is recorded in the Bashkirian Odellfjellet Member and Trikolorfjellet Member. The transgressive part of the second cycle starts in the upper parts of the Odellfjellet Member and Trikolorfjellet Member, covers the whole Minkinfjellet Formation and continues into the lower Wordiekammen Formation (boundary of Cadellfjellet Member/Tyrellfjellet Member; Fig. 4).

These long-term TR cycles are superimposed by smallscale sea-level changes resulting in cyclic successions with a thickness of 1 to $20 \mathrm{~m}$. In central Spitsbergen (Billefjorden Trough), sediments of the upper part of the Odellfjellet Member (Bashkirian) of the Ebbadalen Formation are marked by a distinct cyclicity, which has been connected to a combination of local tectonics and glacio-eustasy (Holliday \& Cutbill, 1972; Gjelberg \& Steel, 1981; Steel \& Worsley, 1984; Dallmann et al., 1999). In the neighboring St. Jonsfjorden Trough, a cyclicity in coeval strata of the Bashkirian Brøggertinden Formation has been described by Ludwig (1989) and proposed as reflecting short-term sea-level changes. Accordingly, we assume that the pronounced cyclicity in the studied sections of the Malte Brunfjellet Formation is also connected to glacio-eustasy.

\section{Paleogeographic setting and lithostrati- graphic scheme}

Serpukhovian to Early Moscovian sedimentation on Svalbard was mainly restricted to the contemporaneous rift troughs, which show an overall similar depositional history. Accordingly, the strata of the Gipsdalen Group are arranged into different lithostratigraphic units, reflecting the regional paleogeography (St. Jonsfjorden Trough: Charlesbreen Subgroup; Inner Hornsund Trough: Treskelen Subgroup; Billefjorden Trough: Campbellryggen Subgroup; Lomfjorden Trough: Malte Brunfjellet and Hårbardbreen formations; West Bjørnøya Trough: Landnørdingsvika, Kapp Kåre, Kapp Hanna and Kapp Dunér formations; Figs. 2, 3).

Not before the Late Moscovian, the sea transgressed from the individual troughs across many of the intermittent highs and a wider, regional sedimentation prevailed over nearly all of Svalbard, reflected in the Dickson Land Subgroup (Wordiekammen and Permian Gipshuken

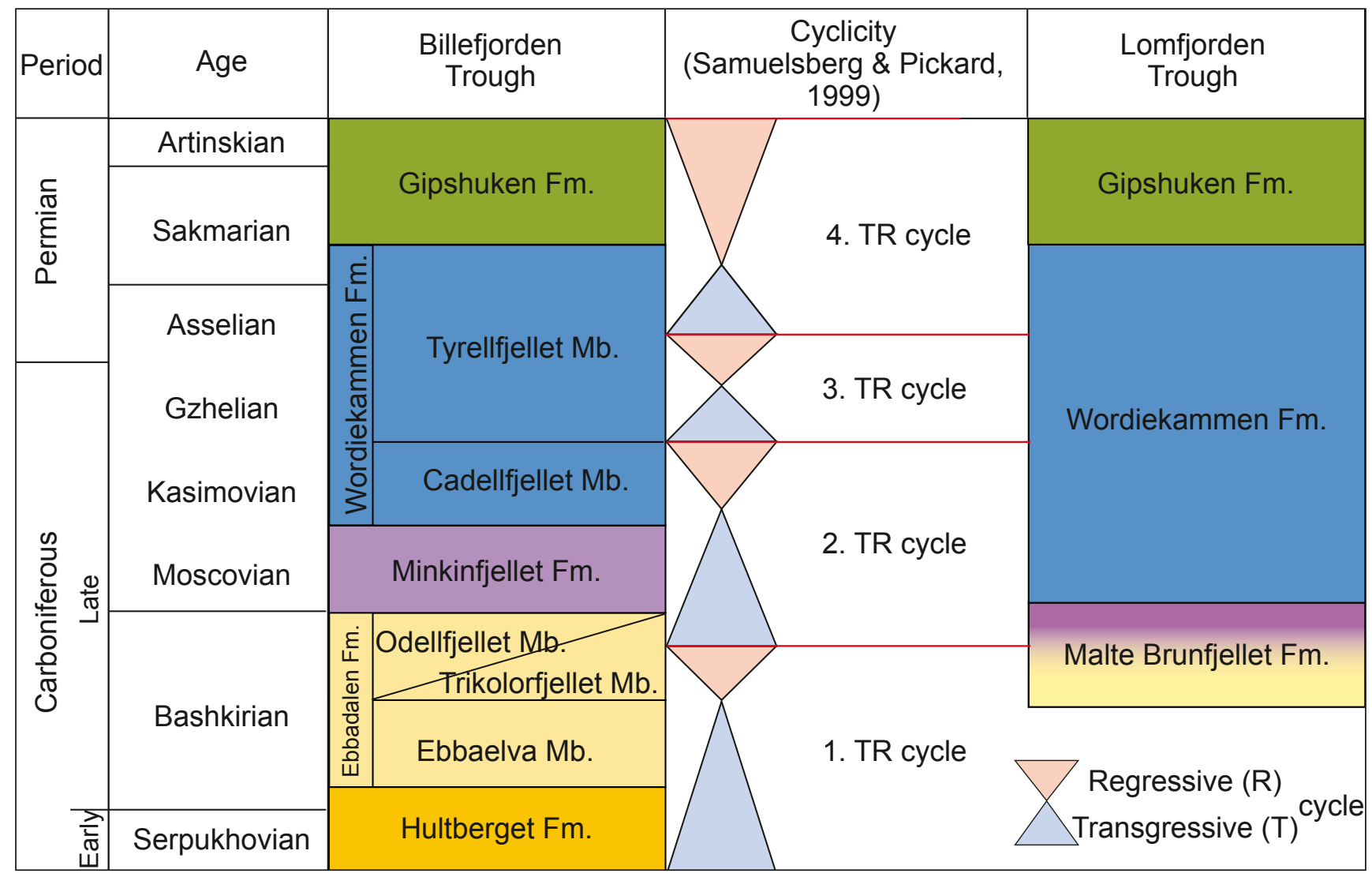

Figure 4. Correlation of the local Carboniferous and Permian lithostratigraphic units of the Billefjorden and Lomfjorden troughs and the stratigraphic range of the transgressive-regressive (TR) cycles as reported by Samuelsberg \& Pickard (1999). Age not to scale. 
formations) in Spitsbergen and Nordaustlandet. The sediments of the Inner Hornsund Trough in southern Spitsbergen are not considered in this study as their depositional history in the Upper Carboniferous Hyrnefjellet and Treskelodden formations (Treskelen Subgroup) with dominating terrestrial sediments reflects a somewhat different depositional evolution than the remaining depositional centers on Spitsbergen. On Bjørnøya, age-equivalent sediments are found in the West Bjørnøya Trough (Gjelberg \& Steel, 1983). In the following, the early Late Carboniferous history of three northern Spitsbergen troughs (St. Jonsfjorden, Billefjorden, Lomfjorden troughs) is described (Figs. 2, 3).

\section{St. Jonsfiorden Trough}

The elongated, NW-SE-trending trough (Fig. 1) is bounded in the east by the Nordfjorden High, while the western continuation is uncertain (Figs. 2, 3; Dallmann et al., 1999). The terrestrial to shallow-marine sediments of the Upper Carboniferous Gipsdalen Group (Charlesbreen Subgroup) are arranged into four formations (Figs. 2, 3). In the northern reaches (Brøggerhalvøya) of the trough, the Brøggertinden Formation is overlain by the Scheteligfjellet Formation. Farther south, in the St. Jonsfjorden area, these local formations are replaced by the Petrellskaret Formation at the bottom and the Tarnkanten Formation on the top (Figs. 2, 3; Dallmann et al., 1999).

The two lower, coeval formations, which have a maximum thickness of $290 \mathrm{~m}$ (Brøggertinden Formation) and $360 \mathrm{~m}$ (Petrellskaret Formation), are dominated by terrestrial red beds, consisting of conglomerates (only Brøggertinden Formation), sandstones, and shales. The sediments reflect alluvial fan and fluvial systems, building out from the steep fault scarps at the western trough margin. Within the uppermost parts of both formations, caliche horizons and marine carbonates are intercalated (Ludwig, 1989, 1990; Dallmann et al., 1999) reflecting initial marine ingressions and coastal, shallowmarine depositional environments.

The two upper formations, also coeval, have a maximum thickness of $120 \mathrm{~m}$ (Scheteligfjellet Formation) and 246 m (Tårnkanten Formation). While the northern Scheteligfjellet Formation consists mainly of fossiliferous shelf carbonates, interbedded with calcareous sandstones, the southern Tårnkanten Formation consists of sandstones and conglomerates interbedded with shales and thin fossil-rich marine limestones (Dallmann et al., 1999). Paleogeographically, the coeval formations reflect a northern opening of the trough and transgression from the north. This $\mathrm{N}-\mathrm{S}$ facies trend marked by marine environments in the north and terrestrial environments in the south is also present in the Lomfjorden Trough.

Conodonts from the Brøggertinden Formation reveal a Bashkirian age (Buggisch et al., 1992, 2001), while the marine-dominated sediments of the overlying Scheteligfjellet Formation are of Early to Middle Moscovian age and partly time-equivalent with the Minkinfjellet Formation and Wordiekammen Formation in the Billefjorden Trough (Dallmann et al., 1999).

\section{Billefjorden Trough}

The NNW-SSE-trending Billefjorden Trough is bounded to the west by the Nordfjorden High and to the east by the Ny-Friesland High (Fig. 1). Up to $1400 \mathrm{~m}$ of red terrestrial (shales, sandstones, conglomerates) and shallow-marine (sandstones, carbonates) strata were deposited from Late Serpukhovian until the Moscovian (Campbellryggen Subgroup; Hultberget Formation, Ebbadalen Formation, Minkinfjellet Formation; Fig. 2; Dallmann et al., 1999). Sedimentation started earlier than in the other troughs, where it was postponed till the Bashkirian.

The lowermost Hultberget Formation (Serpukhovian) comprises a clastic terrestrial red bed succession, for which at least a temporary marine depositional influence has been suggested (Dallmann et al., 1999). The first sediments containing marine fossils (crinoids) occur in the Ebbaelva Member of the overlying Ebbadalen Formation, which is of Baskhirian age (Dallmann et al., 1999).

At this point in time, alluvial, clastic wedges (Odellfjellet Member) built out from the active fault margin of the Billefjorden Fault Zone and laterally interfingered with distal, marine-influenced successions in the basin center (Trikolorfjellet Member). During sedimentation of the overlying Minkinfjellet Formation, which is the uppermost formation restricted to the Billefjorden Trough, an increasing marine influence is recorded by the gradual transition from a terrestrial to a marine succession (Figs. 2, 3). The Minkinfjellet Formation is overlain by the open- to restricted-marine, carbonate platform succession of the Wordiekammen Formation.

\section{Lomfjorden Trough}

Annotation: Although the western boundary (Ny-Friesland High) and the eastern boundary (East Svalbard Platform; Nordaustlandet High; Fig. 3; Harland \& Geddes, 1997; Blomeier et al., 2009) of this depositional center are uncertain, in this manuscript we use the term 'trough', rather than the more descriptive term 'basin'.

In comparison with the well-studied and thick strata of the St. Jonsfjorden and Billefjorden troughs (Fig. 1), the sediments of the Lomfjorden Trough are less thoroughly investigated, have a considerably smaller thickness and lack precise age constraints. Upper Carboniferous sediments are generally poorly exposed in scattered outcrops along the Lomfjorden Fault Zone (Figs. 1, 5). Here, dark terrestrial sediments of the Billefjorden Group 


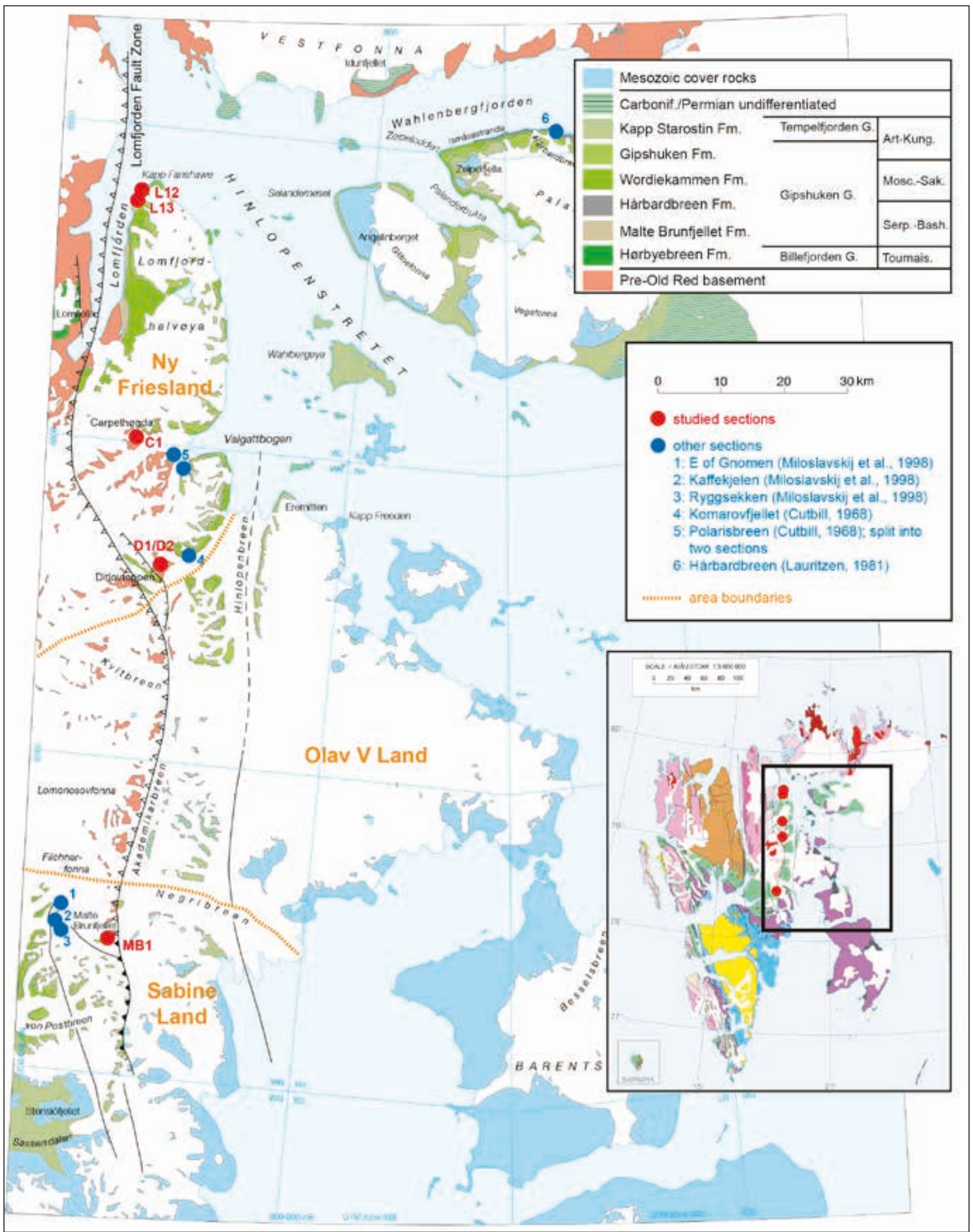

Figure 5. Geologic map of Svalbard and Northeast Spitsbergen including the locations of the sections comprising the transitional Bashkirian to Moscovian strata (modified from Dallmann et al., 1999). 
are overlain by red beds and carbonates of the Malte Brunfjellet Formation, recording the initial phase of the transgression. The strata, reaching a maximum thickness of $80 \mathrm{~m}$ in the type section at Malte Brunfjellet, rapidly thin out to only a few meters in the west (outcrops at Kaffikjelen, Ryggsekken, east of Gnomen; Fig. 5; Miloslavskij et al., 1998), reflecting the trough margin to the neighboring Ny-Friesland High in the west.

Another Upper Carboniferous red bed succession, described from the vicinity of Ditlovtoppen (Polarisbreen, Komarovfjellet; Fig. 5; Cutbill, 1968), was assigned by Cutbill (1968) to the upper part of the Svenbreen Formation and to the lower part of the Minkinfjellet Formation, which are comparable to the Hultberget Formation and Malte Brunfjellet Formation, respectively. East of Lomfjorden, on Nordaustlandet, agequivalent sediments of the Malte Brunfjellet Formation are represented by the Hårbardbreen Formation, which has a thickness between $15 \mathrm{~m}$ and ca. $40 \mathrm{~m}$ and can be subdivided into a lower interval composed of terrestrial (fluvial) deposits and an upper interval composed of marginal marine deposits (Figs. 2, 3; Lauritzen, 1981; Dallmann et al., 1999). The marine influence in the upper part of the Hårbardbreen Formation has also been confirmed by Lauritzen (1981).

Biostratigraphic age determinations based on fusulinids within the uppermost marine limestone beds of the Malte Brunfjellet Formation yield a Moscovian age (Olaussen et al., 1986, referred to in Dallmann et al., 1999). Our determinations from the upper part of the formation (see chapter on age constraints) suggest a Bashkirian age for the sediments of the Malte Brunfjellet Formation.
Figure 6. Outcrop pictures. (A) Section D1/2, Ditlovtoppen. The generally dark sediments of the Billefjorden Group overlie Proterozoic basement rocks (Polarisbreen Group) with an angular unconformity and are in turn conformably overlain by the reddish-weathering Malte Brunfjellet strata. Sedimentary rocks of the Wordiekammen Formation crop out left of the picture. (B) Section D2, Ditlovtoppen. Bedded to massive dolostones from the middle of the Malte Brunfjellet Formation (top of cycle 3; Fig. 7) reflect marine depositional conditions. Hammer for scale. (C) Section C1, Carpethøgda. The bedded carbonate platform strata of the Wordiekammen Formation unconformably overlie igneous basement rocks of Early Devonian age (Raudberget Granite), reflecting a hiatus until the transgression and subsequent platform developed during the Moscovian. (D) Section MB1, Malte Brunfjellet. Dark caliche limestones ('A'; F7) from the upper part of the section (Fig. 7) are overlain by cross-bedded sandstones (' $B$; F3). Hammer for scale. (E) Section MB1, Malte Brunfjellet. At the top of the Malte Brunfjellet Formation, alternating sandstone ('S'; F3) and caliche units (' $C$ '; F7) occur directly below the limestone beds (' $L$ '; F9) of the overlying Wordiekammen Formation. (F) Section MB1, Malte Brunfjellet. Reworked caliche nodules and fragments ('A'; F7) occur as pebble- to cobble-sized intraclasts within a conglomeratic sandstone unit (' $B$ '; F3), on top a massive caliche unit (' $C$ '; $F 7)$. (G) Section MB1, Malte Brunfjellet. The lower part of the section is characterized by a terrestrial succession of mainly red, cross-bedded fluvial sandstones ('A; F1) interbedded with finer, alluvial siltstones to silty claystones (' $B$ '; F2), which are commonly marked by vertical root traces or desiccation cracks, 'C'.

\section{Material and methods}

\section{Field data}

In this study, five sections (from north to south: L12, L13, C1, D2, MB1) have been established in scattered outcrops along the roughly NE-trending Lomfjorden Fault Zone (LFZ) in central and northeast Spitsbergen (Figs. 1, 5; Table 1). The sections comprise the deposits of the Lower

Table 1. Summary of section location, lithostratigraphy, dominant lithologies, samples taken and analytical methods of the five analyzed sections.

\begin{tabular}{|c|c|c|c|c|c|}
\hline & $\begin{array}{c}\text { Malte Brunfjellet } \\
(M B 1)\end{array}$ & $\begin{array}{l}\text { Ditlovtoppen } \\
\text { (D2) }\end{array}$ & $\begin{array}{l}\text { Carpethøgda } \\
\text { (C1) }\end{array}$ & $\begin{array}{c}\text { Lomfjorden } 12 \\
\text { (L12) }\end{array}$ & $\begin{array}{c}\text { Lomfjorden } 13 \\
\text { (L13) }\end{array}$ \\
\hline Section location & $\begin{array}{l}\text { Nunatakk } \\
\text { Malte Brunfjellet } \\
\text { (Sabine Land) }\end{array}$ & $\begin{array}{l}\text { Nunatakk } \\
\text { Ditlovtoppen } \\
\text { (Ny-Friesland) }\end{array}$ & $\begin{array}{l}\text { Nunatakk } \\
\text { Carpethøgda } \\
\text { (Ny-Friesland) }\end{array}$ & $\begin{array}{l}\text { E-side } \\
\text { Lomfjorden } \\
\text { (Ny-Friesland) }\end{array}$ & $\begin{array}{l}\text { E-side } \\
\text { Lomfjorden } \\
\text { (Ny-Friesland) }\end{array}$ \\
\hline $\begin{array}{l}\text { GPS data } \\
\text { (base of section) }\end{array}$ & $\begin{array}{l}\text { N } 78^{\circ} 32.294^{\prime} \\
\text { E } 18^{\circ} 06.969^{\prime}\end{array}$ & $\begin{array}{l}\text { N 7904.629' } \\
\text { E } 18^{\circ} 24.482^{\prime}\end{array}$ & $\begin{array}{l}\text { N } 79^{\circ} 15.441^{\prime} \\
\text { E } 18^{\circ} 10.137^{\prime}\end{array}$ & $\begin{array}{l}\text { N } 79^{\circ} 37.018^{\prime} \\
\text { E } 18^{\circ} 12.132^{\prime}\end{array}$ & $\begin{array}{l}\text { N 79³6.564' } \\
\text { E } 18^{\circ} 09.693^{\prime}\end{array}$ \\
\hline Groups/ Formations & $\begin{array}{l}\text { Wordiekammen Fm. } \\
\text { Malte Brunfjellet Fm. }\end{array}$ & $\begin{array}{l}\text { Wordiekammen Fm. } \\
\text { Malte Brunfjellet Fm. }\end{array}$ & $\begin{array}{l}\text { Wordiekammen Fm. } \\
\text { Raudberget Granite }\end{array}$ & $\begin{array}{l}\text { Wordiekammen Fm. } \\
\text { Malte Brunfjellet Fm. }\end{array}$ & $\begin{array}{l}\text { Wordiekammen Fm. } \\
\text { Malte Brunfjellet Fm. }\end{array}$ \\
\hline Formations & Wordiekammen Fm. & Undefined & Phyllite & Minor & $\mathrm{H}$ \\
\hline Lithology & $\begin{array}{l}\text { Limestone } \\
\text { Caliche } \\
\text { Sandstone } \\
\text { Conglomerate }\end{array}$ & $\begin{array}{l}\text { Limestone } \\
\text { Dolomite } \\
\text { Sandstone } \\
\text { Shale }\end{array}$ & $\begin{array}{l}\text { Limestone } \\
\text { Granite }\end{array}$ & $\begin{array}{l}\text { Dolomite } \\
\text { Sandstone } \\
\text { Shale }\end{array}$ & $\begin{array}{l}\text { Dolomite } \\
\text { Sandstone } \\
\text { Shale }\end{array}$ \\
\hline Samples taken & 40 & $15^{*}$ & $25^{\star 1}$ & 1 & 4 \\
\hline Analysis & Microfacies & $\begin{array}{l}\text { Microfacies } \\
\text { Palynology }\end{array}$ & Microfacies ${ }^{\star 1}$ & Palynology & Palynology \\
\hline
\end{tabular}

${ }^{\star}$ The 15 samples were taken exclusively from the Malte Brunfjellet Formation. Further samples were collected in the Billefjorden Group (D1; Scheibner et al., 2012) and the overlying Wordiekammen Formation (Blomeier et al., 2009).

${ }^{*}$ The 25 samples of section C1 were already investigated in Blomeier et al. (2009). 

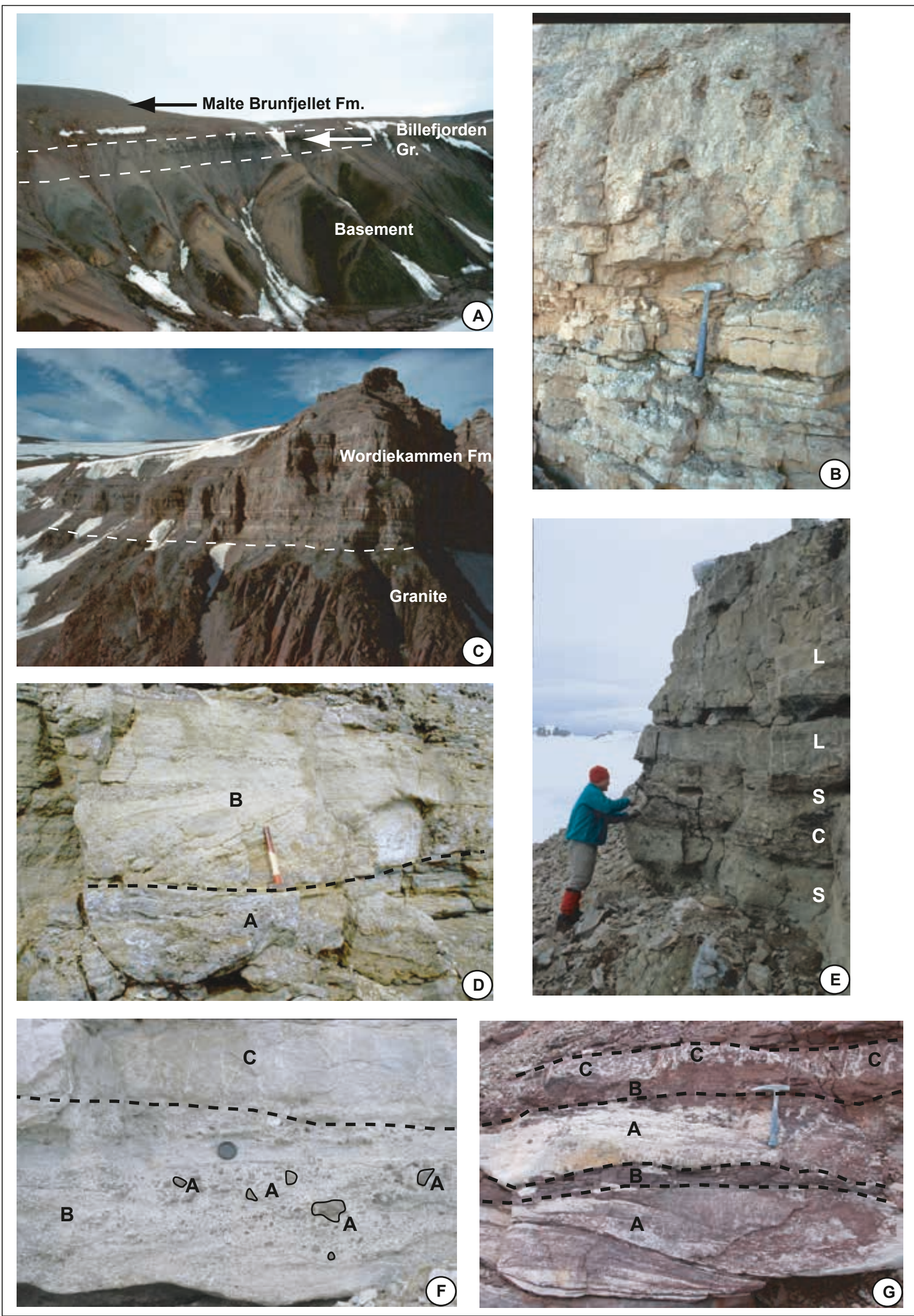
(Serpukhovian) to Upper Carboniferous (Moscovian) Billefjorden Group, the Malte Brunfjellet Formation and Wordiekammen Formation of the Gipsdalen Group, recording the Late Carboniferous transgression in the Lomfjorden Trough. Section Carpethøgda 1 (C1) solely comprises Moscovian limestones of the Wordiekammen Formation, which rest unconformably on the Caledonian Raudberget Granite (Fig. 6C; Tebenkov et al., 1996; Blomeier et al., 2009), indicating a Bashkirian hiatus. However, section $\mathrm{C} 1$ is incorporated in this study, as it provides information on the paleogeography and on the origin of the siliciclastics, which are exposed in the other sections. Sample spacing within the individual sections, depending on lithology and bed thickness, varies from 20 to $500 \mathrm{~cm}$.

\section{Microfacies analysis}

Outcrop investigations are combined with detailed microfacies studies. A total number of 48 over-sized thin-sections $(7.5 \times 10 \mathrm{~cm})$ were used to investigate the microfacies and compositional variation and biostratigraphy (due to the determination of benthic foraminifers) of the sediments in the different locations (Table 1). Carbonates with less than $10 \%$ of detrital quartz grains are described according to the classification schemes of Dunham (1962). On this basis, a semiquantitative facies analysis has been applied and altogether eight microfacies types (MFTs) are described.

\section{Palynology}

Samples for palynology were already analyzed in Scheibner et al. (2012). Standard laboratory preparation techniques were employed using hydrochloric and hydrofluoric acids to remove the carbonate and silicate content of the clastic sediments. The resultant residue was then concentrated by sieving with a $10 \mu \mathrm{m}$ polyester fabric mesh. In order to assess the thermal alteration no oxidants were used. Permanent strew mounts were produced, and polyvinyl alcohol used as the mounting medium followed by Elvacite $2044^{\mathrm{TM}}$ epoxy resin as the embedding medium. The five samples from shales of sections L12 and L13 were either barren or yielded only rare miospores (see next chapter; age constraints).

\section{Age constraints}

Indirect age determinations of the Malte Brunfjellet Formation from the overlying limestone strata of the Wordiekammen Formation yield a Late Moscovian age (Winsnes, 1966; Cutbill, 1968; Miloslavskij et al., 1998). This result is confirmed by direct determinations based on fusulinid assemblages within the uppermost beds of the formation strata in the type locality (Cutbill, 1968; Olaussen et al., 1986, referred to in Dallmann et al., 1999), yielding an Early Moscovian age.
Lønøy (1995) assigned the upper part of the Malte Brunfjellet Formation and the overlying $70 \mathrm{~m}$ of the cyclic limestones of the type locality (MB1) to the Minkinfjellet Formation. In our study this interval contains in the lowermost strata the Malte Brunfjellet Formation and in the rest of the strata the Wordiekammen Formation. In the first $20 \mathrm{~m}$, Lønøy (1995) identified Eostaffella pseudostruvei, Pseudostaffella sp., Profusulinella spp., and Pseudoendothyra spp. and assigned this interval to the Late Bashkirian to Early Moscovian.

Cutbill (1968) identified Profusulinella prisca, P. prolibrovichi and Staffella pseudosphaeroidea in the lowermost beds of the Wordiekammen Formation at the type locality (MB1) and assigned them to the Early Moscovian, although he stated that "specific identifications have doubtful value and those given here should be understood merely as indications of general taxonomic position".

Olaussen et al. (1986, referred to in Dallmann et al., 1999) identified Eostaffella sp., Pseudostaffella sp., Ozawainella sp., and Profusulinella sp., in the uppermost meter of the Malte Brunfjellet Formation strata and in the lowermost succession of the overlying Wordiekammen Formation of the type locality (MB1) and assigned them to the Early Moscovian.

Age determinations in this study are based on the biostratigraphy of large and small benthic foraminifera and palynomorphs (miospores) suggesting a Bashkirian age within a $2 \mathrm{~m}$-thick marine succession $14 \mathrm{~m}$ below the upper boundary of the Malte Brunfjellet Formation in the type locality (MB1; Fig. 7), due to the occurrence of small benthic foraminifera belonging to Archaediscus sp., Asteroarchaediscus sp., Neoarchaediscus sp. and Eostaffella sp. (Fig. 8). According to Pinard \& Mamet (1998), these archaediscids belong to the Bashkirian biozones 20-22 of Mamet (1977) and are most abundant in the middle Bashkirian biozone 21, and only Neoarchaediscus sp. has a stratigraphic range up into the Early Moscovian. Della Porta et al. (2005) noted the extinction of the archaediscids in the Cantabrian Mountains (Spain) in the Early Moscovian. Comparable species are found in the lower part of the Nansen Formation in the Sverdrup Basin and are also assigned to the Bashkirian (Groves et al., 1994).

In section D2, no age-relevant biota were detected within the strata of the Malte Brunfjellet Formation. However, the overlying carbonate platform limestones of the Wordiekammen Formation in sections D1, C1, and MB1 are characterized by Profusulinella sp., Neostaffella sp., Ozawainella sp., Beedeina sp., Fusulinella sp., Wedekindellina sp., Pseudofusulinella sp., and Protriticites sp., indicating a Moscovian to Kasimovian/Gzhelian age (Blomeier et al., 2009).

The Malte Brunfjellet Formation strata in sections L12 
and L13 contain very rare miospores (Lycospora pusilla), which suggest a Visean(?)-Early Baskhkirian age (Scheibner et al., 2012).

\section{Section lithology}

\section{Malte Brunfjellet (MB1)}

At the section location, the strata of the Malte Brunfjellet Formation rest with an angular unconformity on the underlying, folded, and slightly metamorphic red shales of the Neoproterozoic Dracoisen and Wilsonbreen formations (Polarisbreen Group; Miloslavskij et al., 1998; Dallmann et al., 1999). The succession has a total thickness of $60 \mathrm{~m}$ and is subdivided into two parts and is separated by a $32 \mathrm{~m}$-thick mid-gap (due to scee cover) into two fundamentally different sedimentary successions, namely terrestrial clastics in the lower and marginal marine deposits in the upper part (Fig. 7). The lower part, with a thickness of $13 \mathrm{~m}$, consists of two facies, coarse sandstones (F1) and red shales (F2; see facies analysis; Fig. 6G), which interfinger laterally with each other.

The upper, ca. $15 \mathrm{~m}$-thick succession is formed of completely different sediments consisting of pale, crossbedded conglomerates to coarse pebble sandstones (F3), gray to dark gray or even black limestone horizons (F7) and mixed siliciclastic-carbonate sediments (F6; see facies analysis; Fig. 6D, E). The carbonate-dominated sediments yield either marine fossils, such as small benthic foraminifera and echinoderm fragments (F6), or calcareous nodules and laminated horizons (F7; caliche). The different facies are repeatedly deposited onto each other, and altogether nine cycles marked by a defined facies succession are distinguished. The transition into the overlying full-marine, carbonate platform strata of the Wordiekammen Formation is gradual with the formation boundary formally defined on the top of the last sandstone unit (Miloslavskij et al., 1998; Dallmann et al., 1999; Blomeier et al., 2009).

\section{Ditlovtoppen (D1/2)}

Section D1/2 at Ditlovtoppen (Figs. 6A, B, 9) is located in southern Ny-Friesland (Figs. 1, 5) and comprises a basal $40 \mathrm{~m}$-thick succession of dark gray fluvial and alluvial sand, silt and shales (Billefjorden Group, section D1; Scheibner et al., 2012), conformably overlain by a ca. 41 m-thick succession of the Malte Brunfjellet Formation, which in turn conformably and gradually passes upwards into the Wordiekammen Formation (35 m; Fig. 9; Blomeier et al., 2009). Both these younger formations compose section D2.

The succession of the Billefjorden Group onlaps the Neoproterozoic strata of the Dracoisen Formation (Polarisbreen Group; Halverson et al., 2004; Scheibner et al., 2012) with an angular unconformity. Above the Billefjorden Group, reddish, greenish, and yellowish claystones (F5) are intercalated with medium- to thickbedded to massive, ochre dolomites (F8) and greenishgray sandstones (F4) forming the Malte Brunfjellet Formation (Fig. 9). These sediments are arranged into 6 stacked cycles with claystones forming the lower part of each cycle, and either sandstones or dolomites forming the upper part. The boundary to the overlying carbonate platform sediments of the Wordiekammen Formation is gradual and placed on top of the uppermost siliciclastic bed (greenish sandstone horizon) in the succession.

\section{Coastal outcrops on the eastern side of Lomfjorden (L12, L13)}

At the northeastern shore of Lomfjorden, parts of the Malte Brunfjellet Formation are exposed within scattered coastal exposures. Neither the lower nor the upper formation boundaries are exposed (Figs. 1, 5). From these outcrops, only samples have been collected and no sections were logged.

Strata at the first outcrop (Lomfjorden 12, L12) have a thickness of approximately $15 \mathrm{~m}$. The succession starts with a $7 \mathrm{~m}$-thick unit of conglomeratic to coarse-grained, poorly sorted, cross-bedded gray sandstones. Above, a $6 \mathrm{~m}$-thick succession of red, green and dark shales is overlain by a $2 \mathrm{~m}$-thick dolomitic bed with chert nodules, followed by a $2 \mathrm{~m}$-thick greenish-yellow sandstone.

The second outcrop (Lomfjorden 13, L13) exposes an approximately $10 \mathrm{~m}$-thick succession of gray, coarsegrained, cross-bedded conglomeratic sandstones at the base. These sediments are overlain by a dark-gray, wellsorted, cross-bedded sandstone followed by multicolored red, green, gray and dark shales and fine-laminated siltstones, and pyritic sandstones. A $1 \mathrm{~m}$-thick dolomitic bed and red to green sandstones mark the top of the succession.

\section{Carpethøgda (C1)}

At Carpethøgda, deposits of the Malte Brunfjellet Formation are missing entirely, and cyclic carbonate platform strata of the Wordiekammen Formation rest unconformably on basement rocks represented by the Caledonian Raudberget Granite (Figs. 5, 6C, 10; Tebenkov et al., 1996; Blomeier et al., 2009). The base of the platform strata shows a conglomeratic to coarse calcareous sandstone horizon, containing the reworked products of the basement rocks, which were redeposited during the transgression of the granitic horst structure, as well as various bioclasts of the platform biota (e.g., fusulinids, mollusks, corals; Fig. 10). 


\section{Facies analysis}

Altogether nine facies types are recognized; three sandstone-dominated facies (F1, F3, F4), two shale facies (F2, F5), one mixed siliciclastic-carbonate facies (F6), and threecarbonate facies (F7, F8, F9).

\section{F1: Terrestrial redbeds}

Description: This facies type comprises up to $130 \mathrm{~cm}$ of yellowish-white to mainly distinctive red, coarse-grained to pebbly sandstones (Fig. 6G). The sharp bottom surfaces of the sandstone beds are commonly marked by sole marks (scour and tool marks), and the transition to the overlying red shales is gradual. The sandstones are poorly to moderately sorted, and contain conglomerate layers (with clasts of up to $5 \mathrm{~cm}$ in size) and shaly rip-up clasts at the base. The lower parts of the sandstones locally show cross-bedding (F1a), while the upper parts are either horizontally bedded or have a more massive appearance (F1b). In the upper parts of the sandstones, vertical root traces of up to $20 \mathrm{~cm}$ in length and around $1 \mathrm{~cm}$ thickness marked by whitish discolorations are locally present. The sandstones are associated with up to $10 \mathrm{~cm}$-thick, laterally discontinuous red shale horizons or linings (F2), which pinch out laterally. Locally, ironrich incrustations and $\mathrm{cm}$-thick iron-oxide crusts and horizons are present. Overall, the grain size in the lower part of the Malte Brunfjellet Formation shows a fining up gradation.

Occurrence and association: Facies 1 occurs exclusively in the lower part of the Malte Brunfjellet Formation, at section MB1, where it is associated with the red shales (F2; Fig. 7).

Interpretation: see red shale facies (F2)

\section{F2: Red shale}

Description: This facies consists of up to $150 \mathrm{~cm}$ of mostly distinctly reddish, finely laminated or massive, partly silty, shale horizons, which show whitish discolorations in places. Thin, up to $20 \mathrm{~cm}$ thick, sandstone layers (F1) are intercalated within the red shales. Desiccation cracks are present in this facies.

Occurrence and association: F2 occurs together with F1 in the lower part of the Malte Brunfjellet Formation at section MB1 (Fig. 7).

Interpretation: Facies F1 and F2 typically form the lower part of the Malte Brunfjellet Formation at the type locality. They represent a typical fining-upwards succession of a fluvial system. While the lower crossbedded sandstones (F1a) and conglomerates probably reflect the coarse-grained bed load of river channels (Miall, 1996), the upper massive to horizontal-bedded sandstones (F1b) most likely represent overbank deposits (Miall, 1996). The partly silty, finely laminated to massive, red shales (F2) represent vegetated flood plains, marked by root traces and desiccation cracks; Miall, 1996). According to Ludwig (1989), intensive hematite staining has also been observed within overbank deposits of the coeval Brøggertinden Formation in the St. Jonsfjorden Trough in western Spitsbergen. Olaussen et al. (1986, referred to in Dallman et al., 1999) and Miloslavskij et al. (1998) interpreted the lower part of the Malte Brunfjellet Formation as distal alluvial-fan deposits. Similar facies types and depositional environments are described from the lower part of the contemporaneous Brøggertinden Formation in the St. Jonsfjorden Trough (Ludwig, 1989) and the Ebbadalen Formation in the central Spitsbergen Billefjorden Trough (Holliday \& Cutbill, 1972; Dallmann et al., 1999).

\section{F3: Coastal sandstones}

Description: The dominant facies type in the upper part of section MB1 is represented by light-gray, massive to crossbedded sandstones with a thickness from $20 \mathrm{~cm}$ up to 200 $\mathrm{cm}$. Apart from the first two cycles (cycles 1 and 2; Fig. 7) with massive sandstones, all other cycles (cycles 3-9; Fig. 6D) are cross-bedded, probably trough cross-bedded. The bases of the individual sandstone beds are brecciated to conglomeratic, with subangular to subrounded clasts of up to $5 \mathrm{~cm}$ in size, embedded in a coarse sandy matrix. The lowermost cross-bedded sandstone (cycle 3) shows red shaly rip-up clasts at the base. The dips of foresets in cross-beds suggest that paleocurrent flow was directed to the south. The sandstones are dominated by subangular to subrounded quartz grains, with abundant feldspar and mica grains (muscovite and biotite; Fig. 11). Marine or terrestrial fossils are not present. Thin caliche crusts/ layers or nodular caliche fragments/structures with diameters of up to $10 \mathrm{~cm}$ are commonly intercalated within the sandstones (Fig. 6F).

Occurrence and association: The cross-bedded sandstones form the tops of the individual cycles in the upper part of the section MB1, where they are associated with the mixed siliciclastic carbonate facies (F6) and caliche (F7; Figs. 6E, 7).

Interpretation: In contrast to the clear fluvial origin of the sandstones from the lower part of the Malte Brunfjellet Formation, the depositional environment of the sandstones of the upper part of the formation is ambiguous. Trough cross-bedding indicates a fluvial origin (Miall, 1996) although shaly overbank deposits (facies F2) comparable to the lower part of the Malte Brunfjellet Formation are missing. Instead, caliche deposits are present, either as massive horizons or as caliche nodules within the cross-bedded sandstones. These nodular caliche structures could be present due to either in situ caliche formation, which would more strongly support a terrestrial origin, or to redeposition 


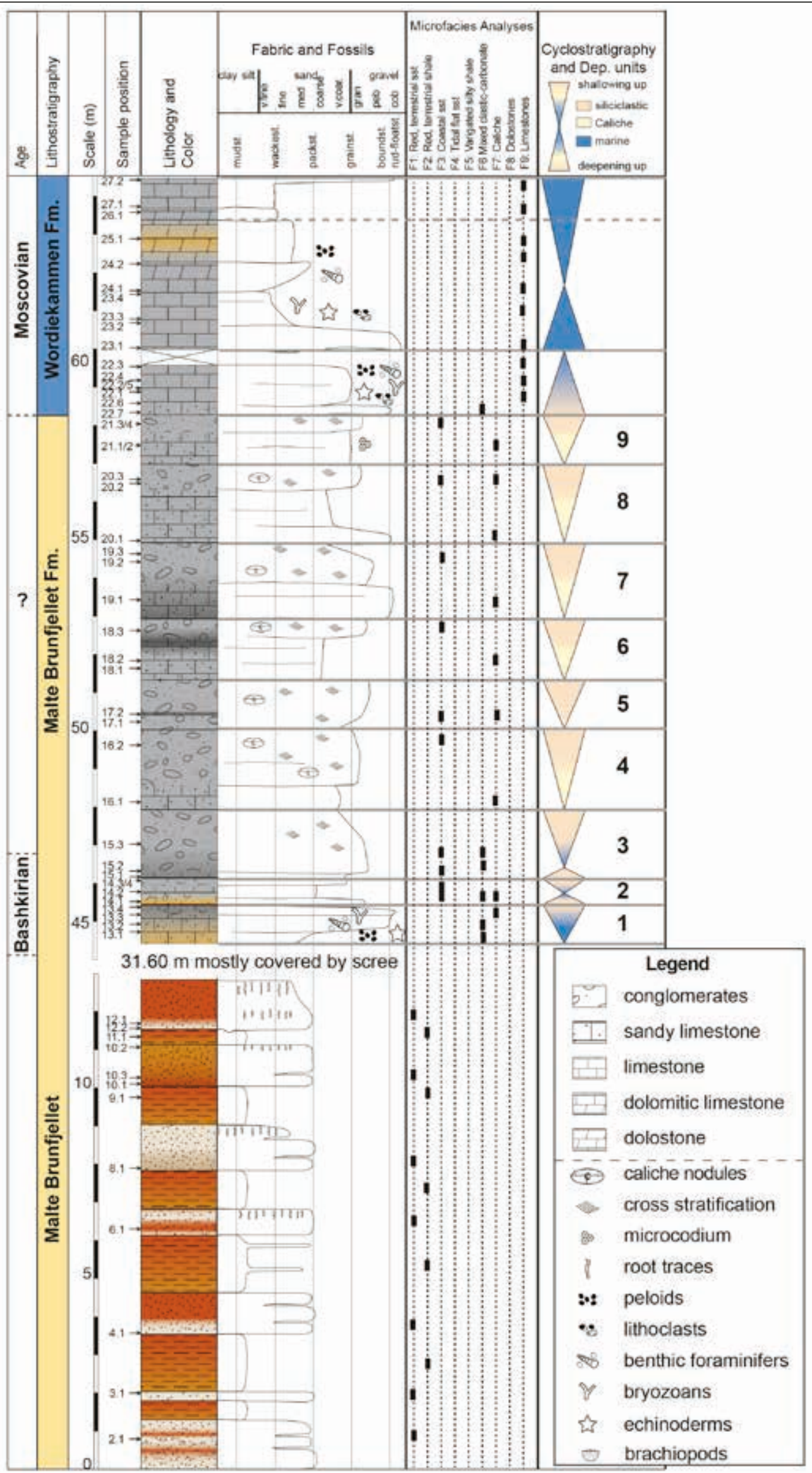

Figure 7. Lithostratigraphy, lithology, fabrics and depositional units of section Malte Brunfjellet 1 (MB1). The microfacies analysis for the Wordiekammen Formation is adopted from Blomeier et al. (2009). The colors in the lithology and color column are an approximation to the colors in nature. 


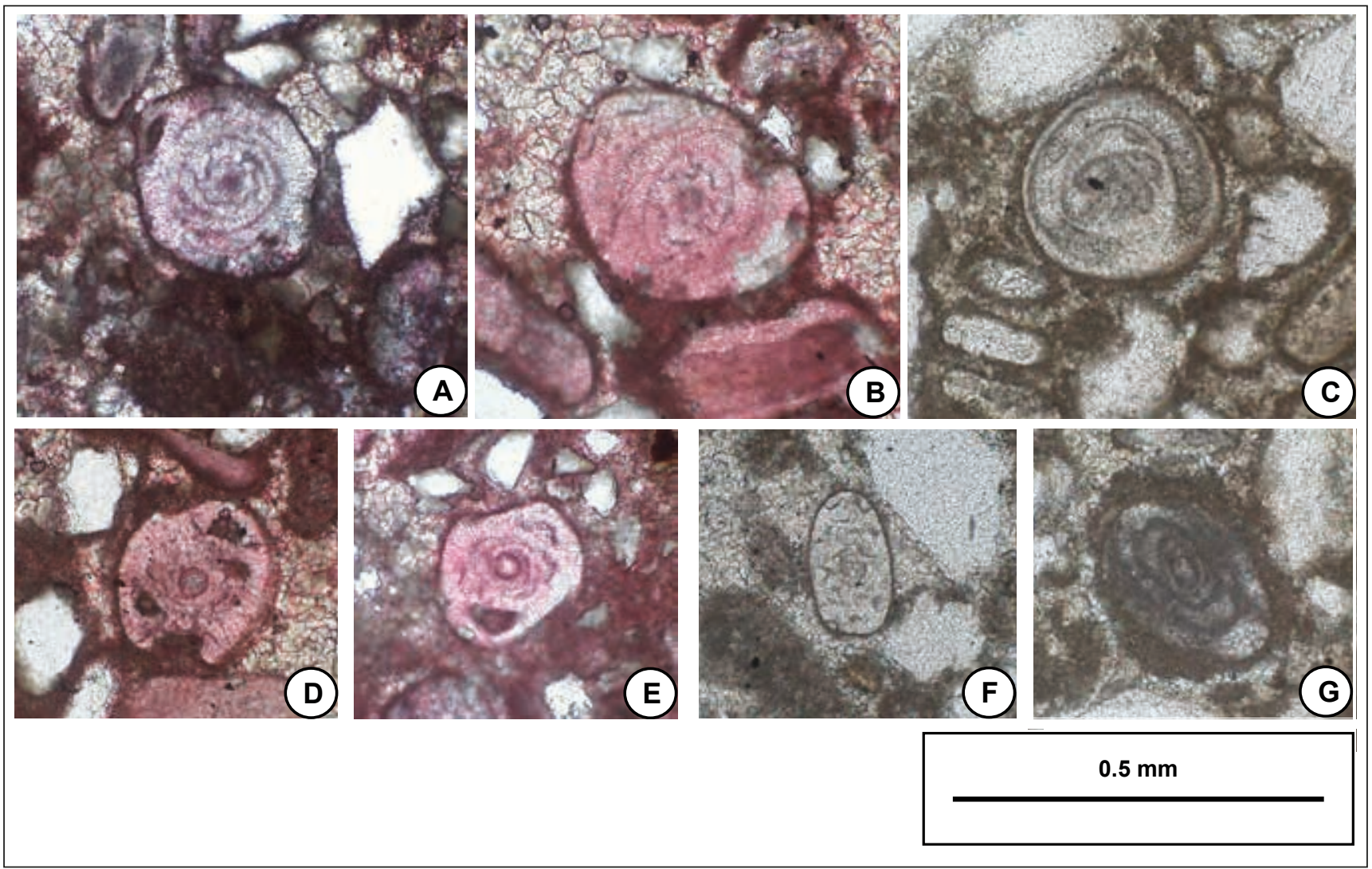

Figure 8. Age-indicative smaller foraminifera: Sample material in pictures $(A),(B),(D),(E)$ is colored with Alizarin $S$ in order to indicate calcite (reddish stained areas). (A) Asteroarchaediscus sp. (B) Asteroarchaediscus sp. (C) Neoarchaediscus sp. (D) Archaediscus sp. (E) Archaediscus sp. (F) Neoarchaediscus sp. (G) Eostaffella sp.

of caliche fragments within either a fluvial or a shallowmarine environment. The similarity of the components of the cross-bedded sandstones to the marine mixed siliciclastic-carbonate facies (F6), only lacking marine fossils, on the other hand, could favor a shallow-marine setting. Furthermore, the composition marked by abundant quartz, feldspar and mica (muscovite and biotite; Fig. 11) suggests a granitic source.

\section{F4: Tidal-flat sandstone}

Description: These light greenish-gray to green sandstones with a maximum thickness of up to $3 \mathrm{~m}$ are very well sorted and composed mainly of fine quartz grains. In some cases a carbonate matrix is present. In one sample the green color is replaced by a yellowishochre color, due to Fe-stained micrite. Large-scale crossbedding is present in places as well as horizontal bedding with vertical bioturbation or root traces, which show a Y-like branched form.

Occurrence and association: The greenish-gray sandstones occur predominantly in the middle to upper parts of section D2. Locally, they are present in sections L12 and L13. In the upper part of section D2 the sandstones occur together with dark-brown sandy dolomites (F8). In the transition to the limestones (F9) of the overlying Wordiekammen Formation, dark to black non-persistent lenses or domed layers occur. The black intervals increase towards the top.

Interpretation: As this gray-green sandstone is the only siliciclastic unit with a carbonate matrix, we interpret this facies to have had a marine influence. The lack of fossils suggests a lagoonal to tidal-flat depositional environment, which occasionally experienced subaerial exposure followed by vegetation growth. Similar ageequivalent, greenish-gray sandstones with a micritic matrix from the Landnørdingsvika Formation of Bjørnøya (Fig. 2) have also been interpreted as tidal-flat sandstones (Gjelberg \& Steel, 1983).

\section{F5: Variegated silty shales}

Description: These up to $12 \mathrm{~m}$ thick, partly silty shales are marked by variable coloration, showing color changes from distinct red at most of the bases of the units to green and more seldom yellow in the middle to upper parts. Fossils have not been observed.

Occurrence and association: In sections D2, L12, and L13 they are the dominant facies types. In combination with dolomites (F8) and tidal flat sandstones (F4), the variegated silty shales form individual cycles with those at the base and either dolomites or tidal-flat sandstones at the top. 


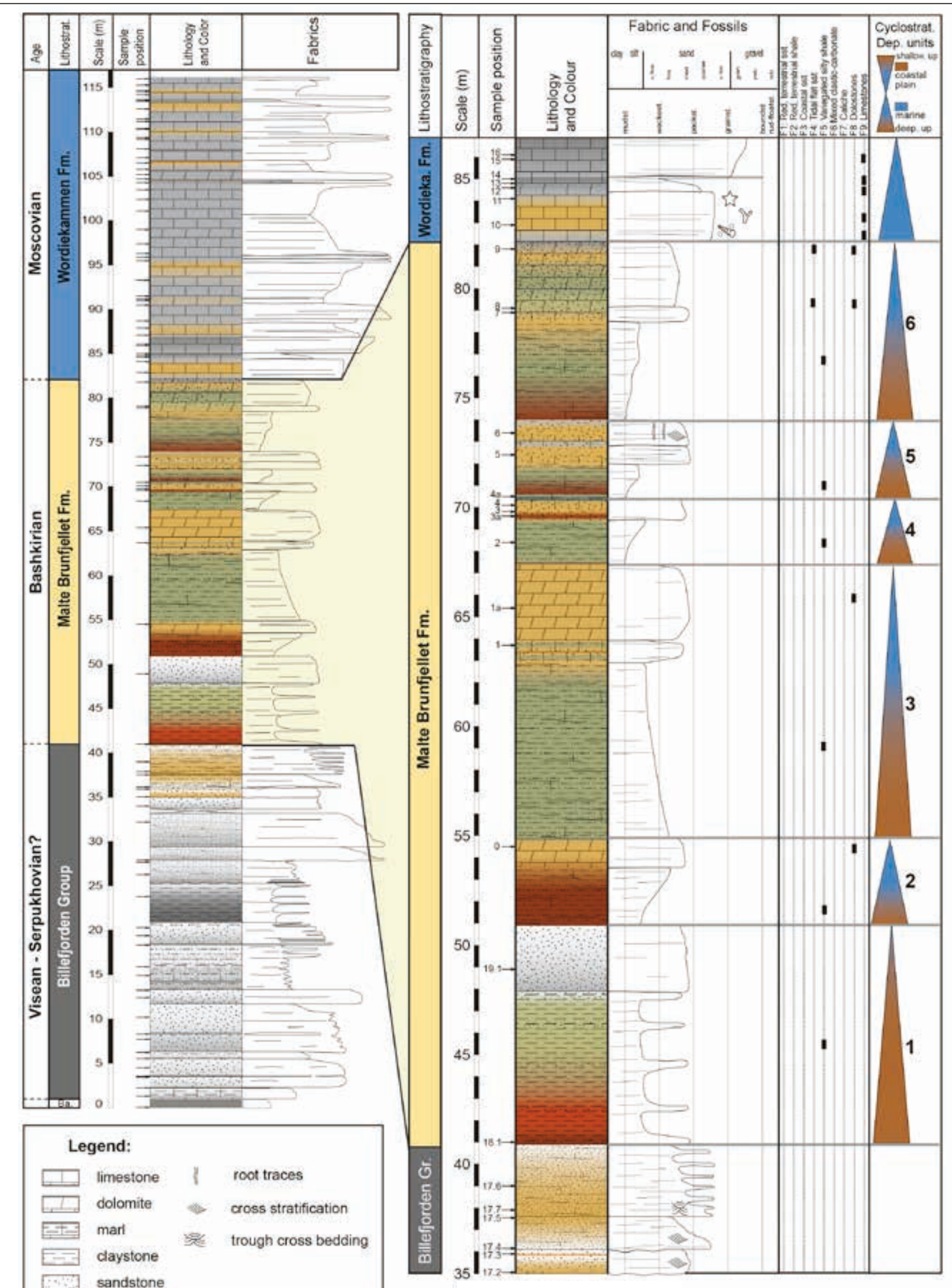

Figure 9. Lithostratigraphy, lithology, fabrics and depositional units of section Ditlovtoppen 1/2 (D1/2), on the left the complete section, on the right the enlargement of the Malte Brunfjellet Formation. Section D1 covers the Billefjorden Group interval, while section D2 covers the Malte Brunfjellet Formation and Wordiekammen Formation interval. The colors in the lithology and color column are an approximation to the colors in nature. For fossil symbols, see Fig. 7. 


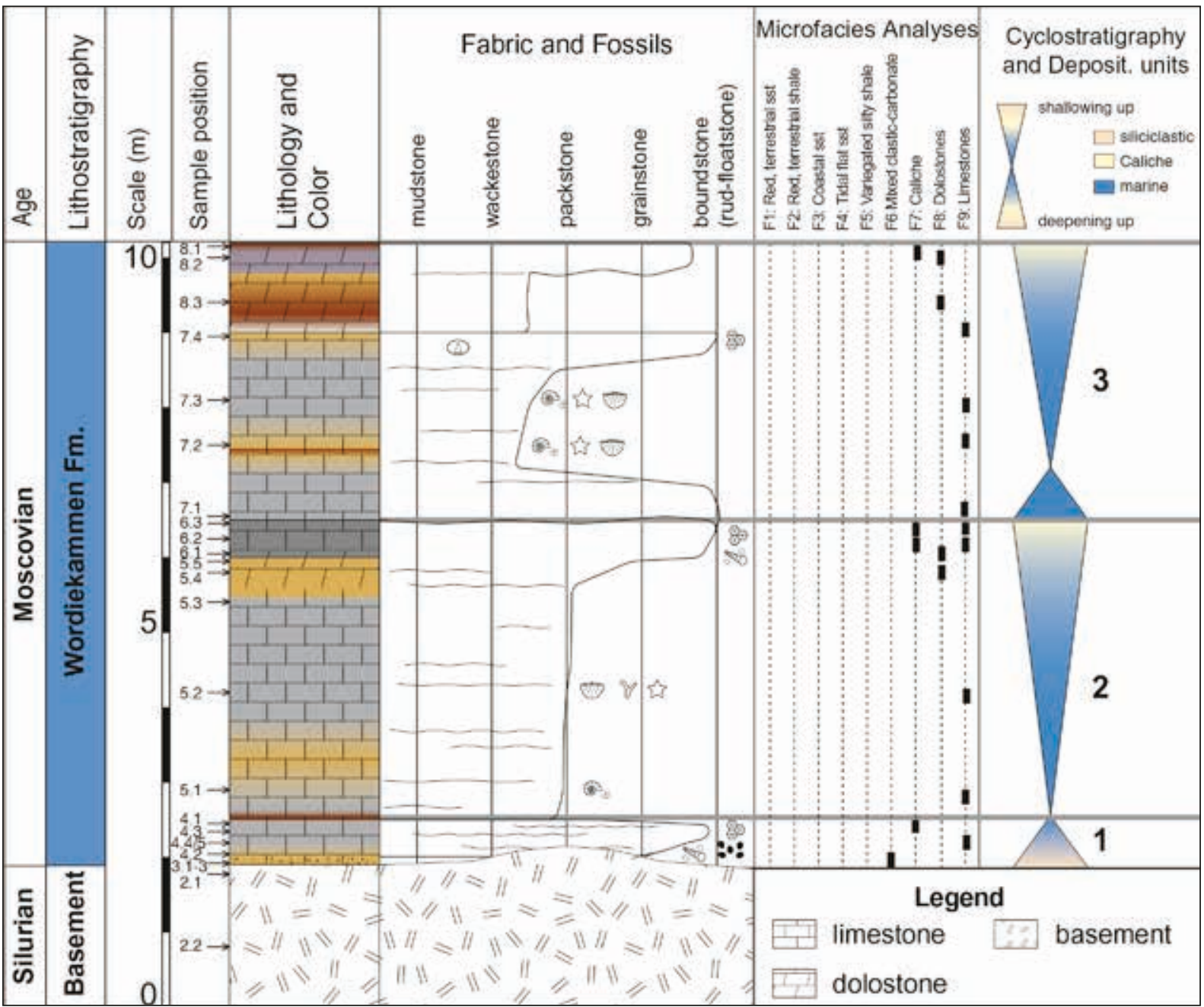

Figure 10. Lithostratigraphy, lithology, fabrics and cyclicity of section Carpeth $\phi g d a 1(C 1)$. The microfacies analysis for the Wordiekammen Formation is adopted from Blomeier et al.(2009). The colors in the lithology and color column are an approximation to the colors in nature. For fossil symbols, see Fig. 7.

Interpretation: The variegated silty shales are probably deposited as playa to coastal-plain sediments, comparable to the sediments of the time-equivalent Ebbaelva Member of the lower Ebbadalen Formation in the Billefjorden Trough (Gjelberg \& Steel, 1981; Johannessen \& Steel, 1992). The color changes from red at the base to green at the top are typical for this type of sediment and can be also observed in Paleozoic profiles from the Midwest USA (West et al., 1997, 2010). These changes might reflect the marine nature of the overlying facies types (dolomites, F8; gray-green sandstones, F4), as during the reducing marine conditions the normally oxidized red mudstones changed their color to green (Schutter \& Heckel, 1985).

\section{F6: Mixed siliciclastic-carbonate facies}

Description: These thin- to thick-bedded sedimentary rocks have a maximum bed thickness of about $75 \mathrm{~cm}$. Peloids, coated grains, arenitic to ruditic bioclasts of bryozoans, echinoderms and smaller foraminifera like archaediscids or eostaffelids (Fig. 8), and siliciclastic grains with sizes of up to $1 \mathrm{~cm}$, are the main components. The components are generally well sorted and are embedded in a micritic to sparitic, grain-supported matrix. This facies is transitional to caliche (F7) and the coastal sandstones (F3). In the transitional areas to the latter two facies types, rare bioclasts are the only evidence of the mixed siliciclastic-carbonate facies; e.g., a rounded bioclast forms a nucleus of a glaebule in caliche (F7) or a small foraminifer is the only marker for the mixed siliciclastic-carbonate facies in what is in all other respects a cross-bedded sandstone facies. Reworked fragments of Caliche (F7) also occur within this facies.

Occurrence and association: This facies type is present in the upper part of section MB1 (Fig. 7), where it is associated with Caliche (F7) and the coastal sandstones (F3) at the bases of the first three cycles.

Interpretation: The occurrence of foraminifera, bryozoans, and echinoderms suggests a shallow-marine origin for this facies. The roundness and abrasion of the components suggest well-agitated conditions due 

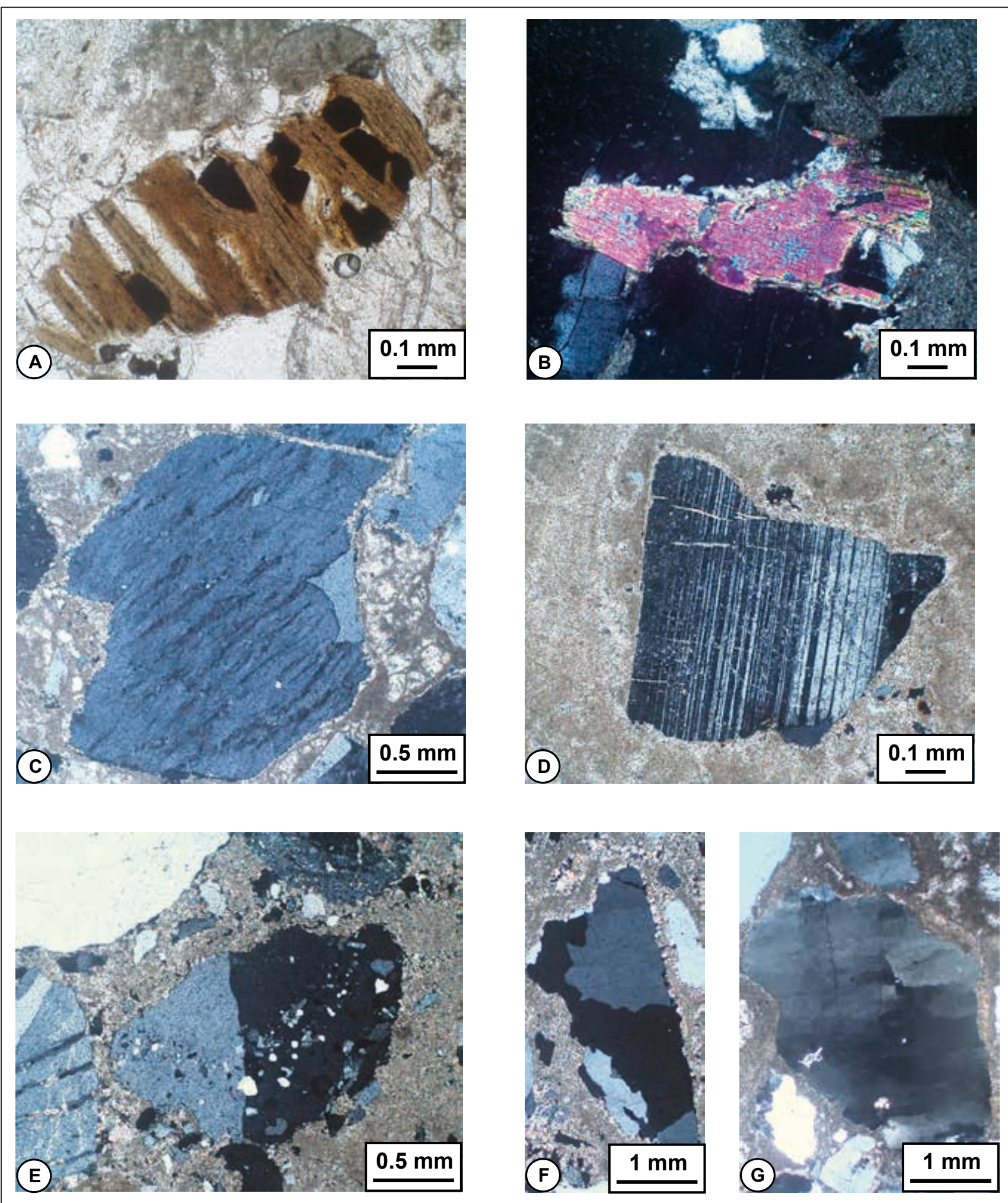

Figure 11. Minerals from the cross-bedded sandstones (F3) from section Malte Brunfjellet. (A) Mica: Biotite. (B) Mica: Muscovite (crossed nicols). (C) Feldspar: Orthoclase (perthite) (crossed nicols). (D) Feldspar: Plagioklase (polysynthetic twin) (crossed nicols). (E) Feldspar: Orthoclase (Carlsbad twin) (crossed nicols). (F) Quartz, a) polycrystalline, $b$ ) with undulatory extinction (crossed nicols).

to wave action within the surf zone of an unprotected coastal area, such as a beach, agreeing with Olaussen et al. (1986, referred to in Dallmann et al., 1999) who suggested amongst other environments deposition in beach spits.
F7: Caliche

Description: These dark gray to black, thin- to thickbedded, limestone beds with a maximum thickness of about $130 \mathrm{~cm}$ show laterally strongly changing 

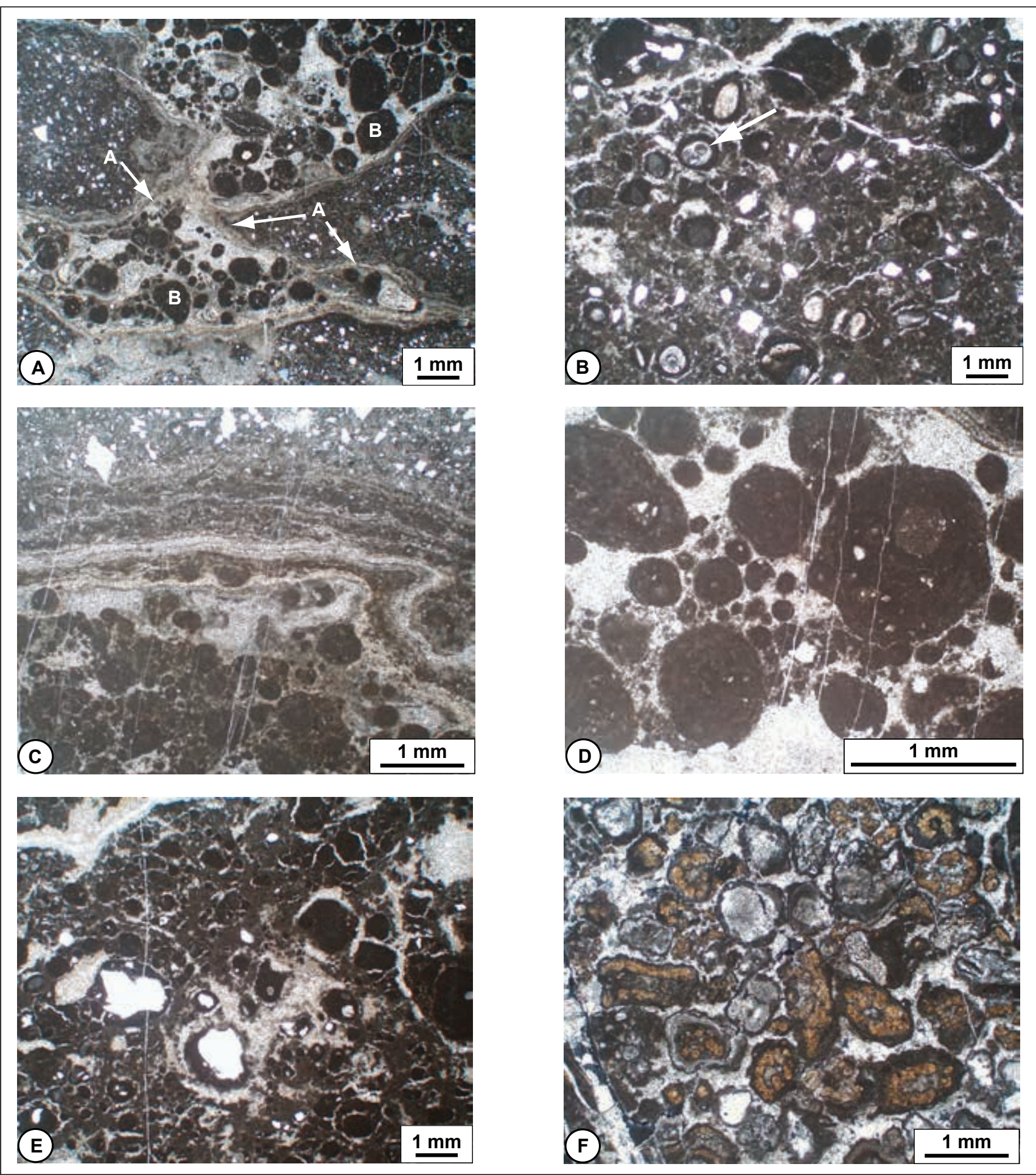

Figure 12. Caliche (F7) from section Malte Brunfjellet. (A) Brecciated caliche, incrusted 'A', infilled with glaebules ' $B$ ' and peloids. (B) Glaebules with circumgranular cracks. The arrow marks a bryozoan fragment. (C) Brown to yellow caliche crust with an irregular surface. (D) Glaebules in a sparitic matrix. (E) Carbonate glaebules with circumgranular cracks. (F) Microcodium in carbonate nodules.

thicknesses with differences of up to $40 \mathrm{~cm}$. The dark limestones are either horizontally laminated or contain rounded nodules. These two features were interpreted by Olaussen et al. (1986, referred to in Dallmann et al., 1999) and Miloslavskij et al. (1998) as stromatolites and oncoids. However, a detailed microfacies analysis revealed a caliche origin for both features.
Alternating, thin, yellowish and brownish micrite layers have produced a locally irregular, wavy horizontal lamination (Fig. 12C). In situ brecciation of the limestones has been observed in places and a few of the larger fragments are completely surrounded by matrix, so that laminar horizons follow irregularities in a former underlying surface (Fig. 12A). The nodules (glaebules), 
which show either an undifferentiated inner micritic structure or a concentric fabric, reach sizes of up to $2 \mathrm{~mm}$ in diameter. Clotted micrite to glaebules occur in layers and laterally discontinuous horizons or fill the spaces between incrusted breccia fragments (Fig. 12A). Circumgranular cracking is present around some of the glaebules (Fig. 12B). Allochthonous microcodium crystals are present only in the uppermost depositional cycle (cycle 9; Figs. 7, 12F). Bioclasts (e.g., bryozoans) are missing completely, except in the transition zones to the mixed siliciclastic-carbonate facies (F6; Fig. 12G) or the coastal sandstone (F3).

Occurrence and association: F7 is present only in the upper part of the Malte Brunfjellet Formation in section MB1. Caliche horizons occur at all bases of cycles 4 to 9 , with the exception of unit 5 , which is formed entirely of the coastal sandstone (F3; Fig. 7).

Interpretation: The dark-gray to black, laminated or nodular limestones represent calcrete or caliche, a typical paleosol, which forms due to terrestrial accumulation of carbonate at or close to the surface down to the groundwater table (Wright, 2007). Contemporaneous caliche formation is described in the upper parts of the Brøggertinden and Petrellskaret formations from the St. Jonsfjorden Trough (Ludwig, 1990; Dallmann et al., 1999), and from the Landnørdingsvika Formation (Gjelberg \& Steel, 1983) and the Bogevika Member of the Kapp Kåre Formation on Bjørnøya (Stemmerik \& Worsley, 2000), as well as from the Sverdrup Basin (Theriault \& Desrochers, 1993). Caliche formation has not been reported from the Billefjorden Trough.

\section{F8: Dolostones}

Description: The dolomites have a maximum thickness of up to $3.50 \mathrm{~m}$ and can be subdivided in section D2 into two subfacies, a yellowish dolomite and a darker brownish sandy dolomite. The yellowish to ochre medium-bedded to massive dolomite locally shows up to $20 \mathrm{~cm}$-wide, irregular voids, partly filled with calcite cement. The internal structure is mainly brecciated (lithoclasts) with a poor internal sorting and common horizontal and vertical cracks and horizontal vugs. The matrix of the individual lithoclasts is micritic. The micrite normally has a massive appearance but also shows an indistinct, wavy undulating lamination in places. Apart from the lithoclasts and rare to common quartz grains there are no other components. The matrix between the lithoclasts is a silty to fine-sandy, Fe-stained micrite resemling a mudstone.

The brownish sandy dolomite is dominated by quartz grains which also occur partly in the wavy laminated dolomite. Within these micritic areas, large rhombohedral dolomite cystals are present and may dominate the matrix. This subfacies is partly silicified.

Occurrence and association: The yellowish dolomites occur mainly in the lower part of the Malte Brunfjellet
Formation of section D2, while the darker, brownish sandy dolomites dominate in the upper part of the Malte Brunfjellet Formation of section D2. Dolomites are also present in sections L12 and L13.

Interpretation: The wavy undulating parts resemble a caliche. The dolomitic facies type with no biogenic components can be interpreted as sabkha deposits, which might have been subaerially exposed.

\section{F9: Shallow-marine limestones}

Description: According to Blomeier et al. (2009) the shallow-marine limestones can be subdivided into 15 microfacies types, which can be grouped into nonbiotic, bioclastic and reefal facies deposited on a mid- to inner platform.

Occurrence and association: The shallow-marine limestones belong to the Wordiekammen Formation which was deposited on top of the sediments of the Malte Brunfjellet Formation.

Interpretation: The 15 microfacies types were deposited in subtidal to supratidal environments and reveal a prominent stacking pattern of shallowing-upward cycles, bounded by distinct discontinuity surfaces (Blomeier et al., 2009).

\section{Discussion}

The following discussion focuses on the provenance of the clastic material, the depositional evolution of the Malte Brunfjellet Formation, and the paleogeographic setting of the Lomfjorden Trough. Furthermore, we discuss the long- and short-term cyclicity of the upper part of the Malte Brunfjellet Formation and combined with the biostratigraphic interpretation of the biota we will discuss the timing of the first, Late Paleozoic Svalbard-wide transgression. The results of the present study require a re-evaluation and extension of the formal definition of the Malte Brunfjellet Formation, established in the 'Lithostratigraphic Lexicon of Svalbard' by Dallmann et al. (1999).

\section{Provenance of the clastic material}

The abundant quartz, mica and feldspar grains in the deposits from the upper part of the Malte Brunfjellet Formation in section MB1 point to a granitic source of the clastic material. On Svalbard, granitic intrusions were emplaced during the Caledonian orogeny and are dated to Silurian (432 $\pm 10 \mathrm{Ma}$; Tebenkov et al., 1996) to Early Devonian (420-405 Ma; Gayer et al., 1966; Hjelle \& Lauritzen, 1982). A number of these igneous intrusions are located within the investigated area and most likely had a substantial influence on sedimentation, 
morphology and the paleogeography of the Lomfjorden Trough itself during the Bashkirian. The most important of these granitic intrusions is the Newtontoppen Granite, located in Ny-Friesland (Fig. 1). Smaller outcrops of Caledonian granite are located at Carpethøgda (Raudberget Granitoid; section C1) and at Ekkoknausane (Fig. 1; Tebenkov et al., 1996).

Within the southern reaches of the Lomfjorden Trough, the Newtontoppen and Ekkoknausane granites (Fig. 1), which are located $25 \mathrm{~km}$ northwest and $40 \mathrm{~km}$ north, respectively, section MB1, most probably acted as source areas for the clastic material of the sandstones in the upper part of the Malte Brunfjellet Formation strata at the type locality. Farther north, at Ditlovtoppen (section D2), another source area for the siliciclastic material could have been the Raudberget Granite at Carpethøgda (section $\mathrm{C} 1$ ), which was subaerially exposed during the sedimentation of the Malte Brunfjellet Formation.

\section{Depositional history of the Malte Brunfjellet Formation}

The redbed succession (F1, F2) forming the lower part of the Malte Brunfjellet Formation in section MB1 in the southern part of the Lomfjorden Trough (Fig. 1) is interpreted to represent the deposits of alluvial fans as well as rivers and alluvial plains in an arid to semi-arid climate. Evidence for marine incursions has not been found within the Lomfjorden Trough (Fig. 1) at this early point in time. A similar contemporaneous facies is present in the Ebbadalen Formation (Odellfjellet Member) of the Billefjorden Trough (Johannessen \& Steel, 1992; Dallmann et al., 1999) and the Brøggertinden Formation of the St. Jonsfjorden Trough (Ludwig, 1989; Dallmann et al., 1999).

The first marine sediments (F6) occur in the upper part of the Malte Brunfjellet Formation in section MB1, reflecting a near-shore depositional environment. Associated with coastal sandstones (F3) and caliche limestones (F7), the strata reflect an agitated, marginalmarine environment, which was marked by quickly alternating terrestrial and shallow-marine conditions. Olaussen et al. (1986, referred to in Dallmann et al., 1999) interpreted the upper part of the Malte Brunfjelllet Formation as fan delta deposits with fluvio-marine and subtidal channels, subtidal to intertidal bars, intertidal flats and beach deposits, clearly indicating a marginalmarine setting. In our view, their interpretation was based on a misidentification of the dark limestones of this study (caliche; F7), which were interpreted as stromatolitic and oncolithic in origin, suggesting a fully marine environment. Our investigations, in contrast, clearly indicate a terrestrial paleosol (caliche) environment for this facies. A similar misinterpretation of caliche structures was made by Holliday (1966) for the upper part of the Brøggertinden Formation (St. Jonsfjorden Trough), where the laminated fabric of the limestones was interpreted as algal structures. Later, Fairchild (1982) and Ludwig $(1989,1990)$ correctly identified these structures as caliche. The scarce occurrence of marine organisms in the caliche horizons in the two lower cycles (1 and 2; Fig. 12G) at Malte Brunfjellet, however, suggests the possibility of a paleosol formation in a former coastal depositional environment. Wright (1994) discussed the evolution of such paleosols in shallow-marine host rocks. If the shallow-marine carbonates are completely replaced by caliche, it would be possible that all of the thick, persistent dark limestones (F7) could represent replaced marginal marine carbonates.

Farther north at Ditlovtoppen (section D2), the recurrent deposition of shales, dolomites and sandstones within the whole section is interpreted to reflect a generally more protected coastal environment, marked by the deposition of generally finer sediments than in the south. Suspended, very fine-grained particles, probably brought in by rivers, accumulated in a more distal pro-delta or lagoonal area under quiet water conditions. During times of high sea level, increased proportions of fine lime mud accumulated on the drowned flats and marine carbonate beds (dolomites, F8) developed.

The different depositional environments of the two areas (north vs. south) suggest a marine-terrestrial gradient similar to the gradient of the Scheteligfjellet Formation and Tårnkanten Formation of the Charlesbreen Subgroup in the St. Jonsfjorden Trough (Figs. 2, 3). The sediments of the southern MB1 section indicate predominantly terrestrial environments, comparable with the Tårnkanten Formation, whereas the sediments of the northern D2 section show an enhanced marine influence, which is comparable to the Scheteligfjellet Formation. This distribution of environments has consequences for the paleogeographic setting and is discussed below.

All sections, however, show a gradual transition to the overlying Wordiekammen Formation, reflected by an increase in intercalations of marine limestones and decrease of terrestrial deposits (sandstones, calcretes) towards the top, recording a successive development to fully marine conditions within the entire trough during the transgression.

\section{Paleogeographic setting}

In contrast to the Billefjorden Trough, where up to $3000 \mathrm{~m}$ of sediment accumulated during the deposition of the Billefjorden Group, Hultberget Formation and Ebbadalen Formation, the Lomfjorden Trough shows an infill of only $83 \mathrm{~m}$ for the same time period at section $\mathrm{D} 1 / 2$ and $60 \mathrm{~m}$ at section MB1. Lauritzen \& Worsley (1975) mention a slightly thicker infill of $100 \mathrm{~m}$ close to Lomfjorden. Similar to the Billefjorden Trough and the St. Jonsfjorden Trough, we assume that the Lomfjorden Trough also had an opening to the marine realm in 


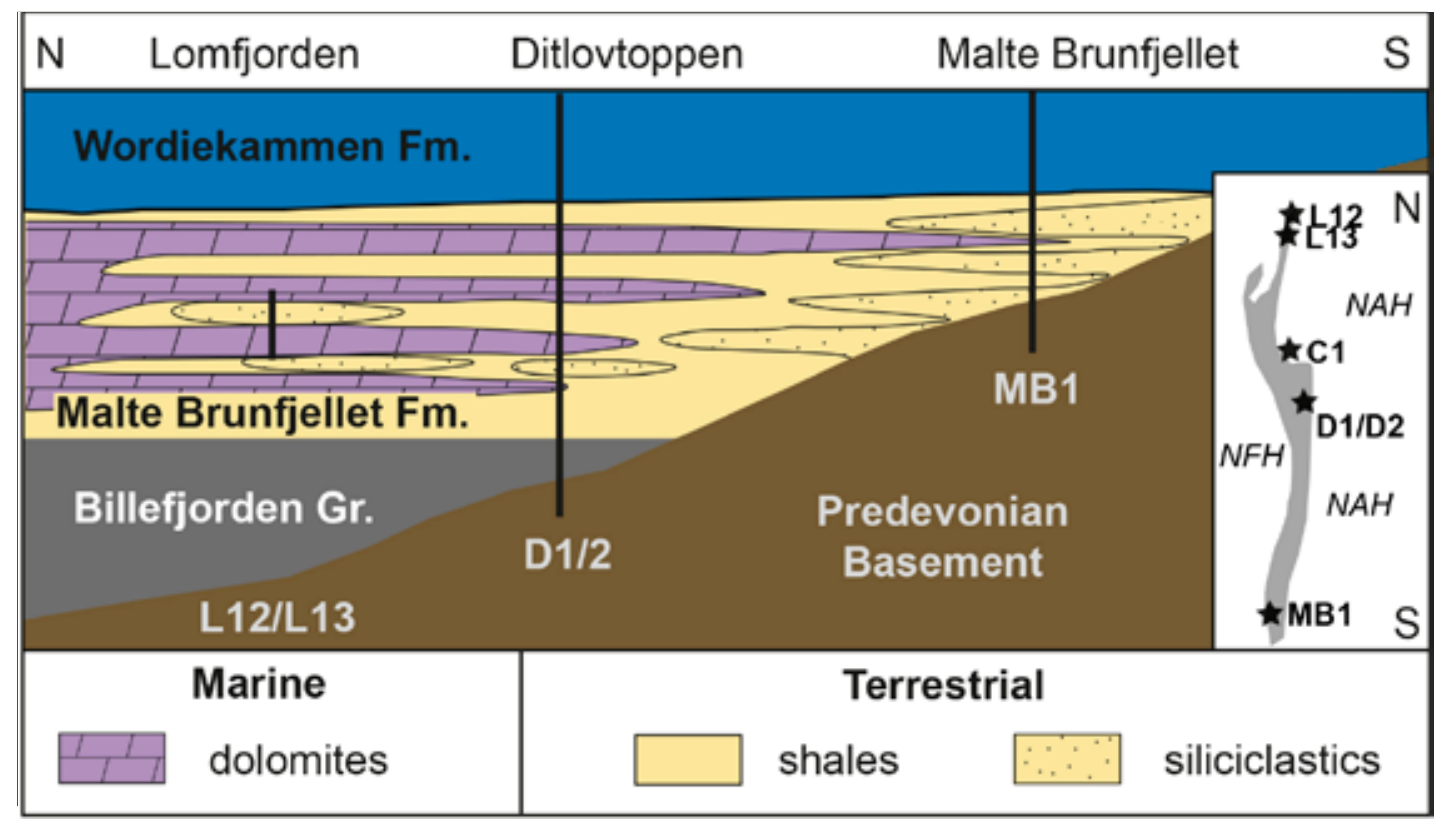

Figure 13. Simplified N-S transect of the Lomfjorden Trough. The presence of sedimentary rocks of the Billefjorden Group in the Lomfjorden and Ditlovtoppen areas and the dominance of marine sediments in section D2 document the successive infill of the Lomfjorden Trough from a northerly direction. Siliciclastics were shed from the Ny-Friesland High (NFH) and Nordaustlandet High (NAH). Section C is located outside the Lomfjorden Trough (see inset for locations of sections; Fig. 1).

the north. In the Billefjorden Trough, the Ebbadalen Formation thickens and shows an increasingly marine influence to the north (Holliday \& Cutbill, 1972; Steel \& Worsley, 1984; McCann \& Dallmann, 1996). In the St. Jonsfjorden Trough, a northwards opening is suggested in view of the deposition of mainly terrestrial sediments in the south (Tårnkanten Formation), while sediments of the contemporaneous Scheteligfjellet Formation (north) already consist to a substantial degree of marine limestones (Dallmann et al., 1999).

According to Cutbill \& Challinor (1965), a northward opening to the marine realm and increasing maturity of the Lomfjorden Trough is suggested by the following features: terrestrial, Early Carboniferous sediments of the Billefjorden Group are present only in the northern areas of the trough (Lomfjorden, section D1, Fig. 5; Scheibner et al., 2012), and are missing in the south (Malte Brunfjellet), reflecting the existence of a deposcenter during Early Carboniferous time in the northern reaches of the trough.

The formation of dolomites and the absence of coarse siliciclastics in the Malte Brunfjellet Formation at Ditlovtoppen (section D2) suggest a more distal location from a terrestrial source area. In contrast, the upper strata of the Malte Brunfjellet Formation in the south (section MB1) are characterized by coarse clastic intercalations, reflecting a closer proximity to the terrestrial source area (F3; Fig. 13). The first marine sediments in this section occur only in the last $15 \mathrm{~m}$ of the Malte Brunfjellet Formation (Fig. 13).
A northward marine opening of the Lomfjorden Trough would imply the absence of a southern Bashkirian connection towards the Billefjorden Trough in the Malte Brunfjellet area, as suggested by Harland \& Geddes (1997). These authors suggested the existence of only one extended basin instead of the individual and contemperanous rift basins in central and eastern Spitsbergen. This basin, the East (Spitsbergen) Basin, was bounded in the west by the Nordfjorden High and in the east by the East Svalbard Platform (Nordaustlandet High), containing the Billefjorden Trough in the west bounded by the Billefjorden Fault Zone, whereas the Lomfjorden Trough would have been located in the eastern part of the basin (Harland \& Geddes, 1997). However, a western opening of the Lomfjorden Trough to the Billefjorden Trough would be contradictory to the westward thinning of the Malte Brunfjellet Formation (Miloslavskij et al., 1998) and an eastward thinning of time-equivalent strata (Ebbadalen Formation) in the Billefjorden Trough (Lønøy, 1995; McCann \& Dallmann, 1996). Paleogeographic reconstructions also suggest a paleohigh (Ny-Friesland High) between the Billefjorden Trough and the Lomfjorden Trough during Bashkirian times (Gjelberg \& Steel, 1983; Lønøy, 1995). A part of this highland area could have been formed by the Ekkoknausane Granite and the Newtontoppen Granite (Fig. 1), which acted as sources of the clastic input within the Malte Brunfjellet Formation. Accordingly, the maximum E-W lateral extent of the Lomfjorden Trough would have been around $10-20 \mathrm{~km}$, assuming a subaerial exposure of the Newtontoppen Granite to the west and of the Carpethøgda Granite to the east of the Lomfjorden Trough. 


\section{Cyclicity}

Long-term cyclicity (transgressive-regressive cycles; TR cycle)

According to the age determinations, the upper part of the formation at Malte Brunfjellet has a Late Bashkirian/ Early Moscovian age, and thus most likely represents the transgressive part of the second TR cycle of Samuelsberg \& Pickard (1999). No age determinations exist for the lower, red, terrestrial succession, which was probably deposited during the first TR cycle (Fig. 4). Because of the minor lateral distribution and the uncertain age of the lower part of the Malte Brunfjellet Formation we refrain from suggesting an exact age assignment for the lower red shales and sandstones.

The upper part of the Malte Brunfjellet Formation in section MB1 and the overlying Wordiekammen Formation certainly belong to the transgressive part of the second TR cycle of Samuelsberg \& Pickard (1999). The six depositional cycles of section D2 probably also belong to the transgressive part of the second TR cycle (Fig. 4), but owing to a lack of age constraints older ages cannot be ruled out. The transgressive part of the second TR cycle correlates very well with the overall sea-level rise from the middle to upper Bashkirian (Fig 2; Ford \& Golonka, 2003; Haq \& Schutter, 2008).

\section{Short-term cyclicity}

The upper part of section MB1 exhibits a prominent short-term cyclicity comprising up to nine depositional cycles, each composed of caliche (F7) at the base and sandstones (F3) at the top (Fig. 7). As already described in the chapter on depositional history, the caliche might represent a former marine environment, while the sandstone beds were deposited in either a coastal or a fluviatile environment. This stacking pattern thus reflects an upward shallowing of the succession.

In section D2, cyclicity is represented by three different facies types. Here, an upward deepening from greenish silty shales of terrestrial origin to yellowish-brown dolomites or gray-green sandstones of marine origin is evident. Overall, six cycles are present in section D2 (Fig. 9).

The causes of this cyclicity are not unambiguous, but the transitional upper boundary to the cyclic limestones of the Wordiekammen Formation in sections MB1 and D2 suggests similar causes for both kinds of short-term cyclicities and hence a similar duration for both types of cycles might be possible. For the Wordiekammen Formation, a 400 kyr cyclicity caused by eustatic sea-level changes has been suggested (Blomeier et al., 2009). If one assumes a $400 \mathrm{kyr}$ cyclicitiy not only for the limestones of the Wordiekammen Formation but also for an individual depositional cycle of the upper part of section MB1, this interval with nine depositional cycles would have a duration of 3.6 Myr. Assuming a duration of $6 \mathrm{Myr}$ for the whole of the Bashkirian (Gradstein et al., 2004), the base of the upper part of the Malte Brunfjellet Formation would be located in the middle Bashkirian, if all of the depositional cycles belong to the Bashkirian. This age would fit well with the expected age determination from the small foraminifera (archaediscids), which have their abundance maximum in the middle Bashkirian biozone 21 of Mamet (1977). In contrast to the 400 kyr cyclicity presented here, Stemmerik et al. (1998) suggested a 100 kyr cyclicity for depositional cycles on Bjørnøya and the Loppa High (Barents Sea). If we adopt this timing of the cyclicity for the upper part of the Malte Brunfjellet Formation in section MB1, these sediments would have a duration of $0.9 \mathrm{Myr}$ and the base of the upper part of the Malte Brunfjellet Formation would be located in the Late Bashkirian.

In section D2 there are only six cycles, but the lack of fossil content precludes an age assignment, comparable to section MB1. To conclude, it can be stated that both biostratigraphy and cyclostratigraphy suggest a Middle to Late Bashkirian age for the upper part of the Malte Brunfjellet Formation regardless of the duration of an individual cycle.

\section{Timing of Late Carboniferous transgressions}

During the Carboniferous, two marine transgressions are recorded within the depositional history of the individual rift troughs of Spitsbergen. The oldest marine conditions are documented exclusively from sediments of the 'Early' Bashkirian Ebbaelva Member of the Ebbadalen Formation in the Billefjorden Trough, which were deposited within the transgressive phase of the first long-term TR cycle of Samuelsberg \& Pickard (1999).

During the transgressive phase of the following longterm TR cycle from the Late Bashkirian to the Early Moscovian, marine conditions are documented in all rift troughs of Spitsbergen. Transitional sediments of this second incursion are present in the central Billefjorden Trough (Trikolorfjellet Member), and in the western St. Jonsfjorden Trough (upper part of the Brøggertinden Formation; Ludwig, 1989). With this study we can for the first time document that this 'Late" Bashkirian ingression also flooded the easernmost Lomfjorden Trough.

From Moscovian time onwards, a shallow shelf covered most of Svalbard and the previous isolated troughs and intermittent highs were covered by cyclic carbonate platfom strata of the Wordiekammen Formation (Hüneke et al., 2001; Blomeier et al., 2009).

\section{Definition of the Malte Brunfjellet Formation}

After Miloslavskij et al. (1998) and Dallmann et al. (1999), the Malte Brunfjellet Formation has a very 
local occurrence, cropping out at the nunataks Malte Brunfjellet, Ryggsekken, Kaffikjelen and the eastern spur of Gnomen in northern Sabine Land (Fig. 5). Despite this local occurrence in central Spitsbergen, a larger areal extent of the Malte Brunfjellet Formation was already considered by the above authors who pointed out its similarity to sediments described by Cutbill (1968) from the Lomfjorden area in northeast Spitsbergen (Fig. 5). In the present paper, additional exposures at Ditlovtoppen (section D2; Figs. 1, 5) and along the eastern coast of Lomfjorden (sections L12, L13; Figs. 1, 5) are assigned to the Malte Brunfjellet Formation, thus leading to an extension of the definition of the formation. These northerly occurrences are already assigned to the Malte Brunfjellet Formation in the current geological map of the Lomfjordhalvøya (Dallmann et al., 2009). The deposition of the Malte Brunfjellet Formation strata is probably related to fault-controlled deposition along the Lomfjorden Fault Zone (Lomfjorden Trough) during early Late Carboniferous times (Miloslavskij et al., 1998), similar to the deposition in the Billefjorden Trough (McCann \& Dallmann, 1996; Harland \& Kelly, 1997). Earlier, the Malte Brunfjellet Formation was considered to belong to the Minkinfjellet Formation (Cutbill, 1968), but Miloslavskij et al. (1998) and Dallmann et al. (1999) rejected this assignment, because both formations reflect deposition within isolated rift troughs. As we have shown in the discussion of the paleogeographic setting, this assumption was correct, as the Lomfjorden Trough is not connected with any other troughs but forms a narrow depositional center of its own. In the following, the extended definition of the Malte Brunfjellet Formation is presented, following the format of Dallmann et al. (1999).

\section{Extension of the definition of the Malte Brunfjellet Formation}

Distribution: The occurrence of the formation is restricted to the expanse of the Early Carboniferous Lomfjorden Trough (Fig. 1). The main outcrops comprise the nunataks of Malte Brunfjellet, Ryggsekken, Kaffikjelen and the eastern spur of Gnomen to the north. The formation also occurs in Sabine Land as well as on the nunatak Ditlovtoppen and the local areas along the eastern coast of Lomfjorden in $\mathrm{Ny}$-Friesland (Fig. 5; Dallmann et al., 2009).

Structural setting: Lomfjorden Trough.

Depositional age: Bashkirian to lowermost

Moscovian(?) (upper part of formation).

Dating method: Foraminifera (archaediscids).

Reference for age: This study.

Overlying units: Wordiekammen Formation.

Underlying units: Neoproterozoic strata in most places; Billefjorden Group at Ditlovtoppen; Oslobreen Group and Billefjorden Group in the northern part of Lomfjorden.

Main lithologies: Sandstone, shale, dolomite, limestone.
Lower boundary definition: The lower boundary is either an angular unconformity above pre-Old Red basement (southern area around the type locality), conformably on top of the underlying sandstones and black shales of the Billefjorden Group (section Ditlovtoppen) or not exposed (northern area on the eastern side of Lomfjorden).

Upper boundary definition: The upper boundary is transitional to the overlying cyclic limestones of the Wordiekammen Formation in the type locality and at section Ditlovtoppen, or covered by scree (eastern side of Lomfjorden).

Description: The description of Dallmann et al. (1999) refers to the original southern area and is extended here in the chapter on facies analysis. In the northern areas of exposure (Lomfjorden, Ditlovtoppen), three additional facies types (gray-green sandstones (F4), variegated, silty shales (F5) and dolomites (F8)), form cyclic strata with variegated shales at the base and dolomites and sandstones at the top.

\section{Conclusions}

Detailed outcrop investigations and microfacies analysis of five sections along the Lomfjorden Fault Zone in eastern Spitsbergen have resulted in a new definition and northward extension of the Late Carboniferous Malte Brunfjellet Formation in eastern Spitsbergen, by including sediments at the nunatak Ditlovtoppen and along the eastern side of Lomfjorden in Ny-Friesland (northeast Spitsbergen). Hitherto, this formation was known only from Sabine Land (central Spitsbergen), although a northern occurrence was anticipated. The strata of the formation represent the early sedimentary fill of the Lomfjorden Trough, a rift trough which subsided due to active tectonic movements during early Late Carboniferous times together with the timeequivalent Billefjorden Trough in central Spitsbergen and the western St. Jonsfjorden Trough. However, the deposits of the Lomfjorden Trough are much thinner than those in the two former troughs.

The investigated sediments of the Lomfjorden Trough reflect a development from a terrestrial setting marked by alluvial/fluvial environments to a marginal-marine, coastal setting characterized by sabkha and near-shore (beach) deposits. The various lithologies are stacked upon each other, forming a pronounced cyclicity. Two different kinds of cyclicities can be observed. In the southern Lomfjorden Trough the upper part of the Malte Brunfjellet Formation is characterized by dominantly shallowing-up cycles with carbonates at the bases and siliciclastic lithologies at the tops. In contrast, cyclicity in the northern Lomfjorden is composed of upwarddeepening cycles with shales at the bases and dominantly carbonates at the tops. This dichotomy has probably resulted probably from deposition within different environments. 
Within the Lomfjorden Trough, the spatio-temporal occurrence and association of the facies reflect a trough opening to the north which resulted in a successive infill of marine deposits to the south. This paleogeographical setting is supported by the exclusive presence of sediments of the underlying Billefjorden Group in the northern part of the Lomfjorden Trough. Furthermore, this marine incursion from the north is congruent with the marine incursions in the western St. Jonsfjorden Trough and the central Billefjorden Trough. Biostratigraphy based on the presence of smaller foraminifera (archaediscids) in the marine sediments in the upper part of the Malte Brunfjellet Formation suggests a Middle to Late Bashkirian age for this interval. This age determination is supported by cyclostratigraphy, even if the range of the cyclicity remains uncertain. It might vary from 100 to 400 kyr in the upper part of the Malte Brunfjellet Formation. These results support a two-stage drowning of Svalbard in the Late Carboniferous: in the first stage, the marine incursion started during the Middle to Late Bashkirian in the three northern depositional troughs from northerly directions and led to the deposition of the first marine sediments in various formations (St Jonsfjorden Trough: Brøggertinden Formation, Scheteligfjellet Formation; Billefjorden Trough: Ebbadalen Formation, Minkinfjellet Formation; Lomfjorden Trough: Malte Brunfjellet Formation). In the second step, from Moscovian times onwards, sea level rose and started to cover the adjacent structural highs as well, leading to the deposition of the shallow-marine carbonate deposits of the Wordiekammen Formation. Since that time, no individual depositional systems existed throughout Svalbard during the rest of the Paleozoic.

Acknowledgements. We would like to thank Winfried Dallmann, Karsten Piepjohn and Barbara Reinicke for supporting us during fieldwork in the years 2004 and 2005. The staff from the logistics department of the Norwegian Polar Institute and the helicopter crew from Airlift are thanked for making it possible to work in the remote areas of northeast Spitsbergen. We thank Atle Mørk and Hans Arne Nakrem for their constructive reviews. This project was funded by the DFG and DAAD (DFG grant SCH 685/3-1, DAAD grant D/05/26074).

\section{References}

Blomeier, D., Scheibner, C. \& Forke, H. 2009: Facies arrangement and cyclostratigraphic architecture of a shallow-marine, warm-water carbonate platform: the Late Carboniferous Ny Friesland Platform in eastern Spitsbergen (Pyefjellet Beds, Wordiekammen Formation, Gipsdalen Group). Facies 55, 291-324. doi: http://dx.doi. org/10.1007/s10347-008-0163-3.

Buggisch, W., Piepjohn, K., Thiedig, F. \& von Gosen, W. 1992: A Middle Carboniferous conodont fauna from Blomstrandhalvöya (NWSpitsbergen): Implications on the age of post-Devonian karstification and the Svalbardian deformation. Polarforschung 62, 83-90.

Buggisch, W., Joachimski, M., Lützner, H., Thiedig, F. \& Hüneke, H. 2001: Conodont stratigraphy of the Carboniferous and Permian strata from Brøggerhalvøya and the Billefjorden Trough. Geologisches Jahrbuch B91, 637-689.

Cutbill, J.L. 1968: Carboniferous and Permian stratigraphy of $\mathrm{Ny}$ Friesland, Spitsbergen. Norsk Polarinstitutt Årbok 1966, 12-24.

Cutbill, J.L. \& Challinor, A. 1965: Revision of the stratigraphical scheme for the Carboniferous and Permian rocks of Spitsbergen and Bjørnøya. Geological Magazine 102, 418-439. doi: http://dx.doi. org/10.1017/S0016756800053693

Dallmann, W.K., Gjelberg, J.G., Harland, W.B., Johannessen, E.P., Keilen, H.B., Lønøy, A., Nilsson, I. \& Worsley, D. 1999: Upper Paleozoic lithostratigraphy. In Dallmann, W.K. (ed.): Lithostratigraphic lexicon of Svalbard: Upper Paleozoic to Quaternary bedrock, review and recommendations for nomenclature use, Norsk Polarinstitutt, Tromsø, pp. 25-126.

Dallmann, W.K., Ohta, Y., Elvevold, S. \& Blomeier, D. 2002: Bedrock map of Svalbard and Jan Mayen, 1:750,000. Norsk Polarinstitutt Temakart 33.

Dallmann, W.K., Piepjohn, K., Elvevold, S. \& Blomeier, D. 2009: Geological map Svalbard 1:100,000, sheet D5G Lomfjordhalvøya, Norsk Polarinstitutt Temakart 44.

Della Porta, G., Villa, E. \& Kenter, J.A.M. 2005: Facies distribution of fusulinida in a Bashirian-Moscovian (Pennsylvanian) carbonate platform top (Cantabrian Mountains, NW Spain). Journal of Foraminiferal Research 35, 344-367. doi: http://dx.doi. org/10.2113/35.4.344.

Dunham, R.J. 1962: Classification of carbonate rocks according to depositonal texture. In Ham, W.E. (ed.): Classification of carbonate rocks, American Association of Petroleum Geologists Memoirs 1, pp. 108-121.

Fairchild, I.J. 1982: The Orustdalen Formation of Brøggerhalvøya, Svalbard: A fan delta complex of Dinantian/Namurian age. Polar Research 1982, 17-34. doi: http://dx.doi.org/10.3402/polar. v1982i1.6997.

Ford, D. \& Golonka, J. 2003: Phanerozoic paleogeography, paleoenvironment and lithofacies maps of the circum-Atlantic margins. Marine and Petroleum Geology 20, 249-285. doi: http://dx.doi. org/10.1016/S0264-8172(03)00041-2.

Gayer, R.A., Gee, D.G., Harland, W.B., Miller, J.A., Spall, H.R., Wallis, R.H. \& Winsnes, T.S. 1966: Radiometric age determinations on rocks from Spitsbergen. Norsk Polarinstitutt Skrifter 137, 1-39.

Gjelberg, J.G. \& Steel, R.J. 1981: An outline of Lower-Middle Carboniferous sedimentation on Svalbard: Effects of tectonic, climatic and sea level changes in rift basin sequences. In Kerr, J.W. \& Fergusson, A.J. (eds.): Geology of the North Atlantic Borderlands - Memoir 7, Canadian Society of Petroleum Geologists, Calgary, Canada, pp. 543-561.

Gjelberg, J. \& Steel, R. 1983: Middle carboniferous marine transgression, Bjørnøya, Svalbard: facies sequences from an interplay of sea level changes and tectonics. Geological Journal 18, 1-19. doi: 10.1002/gj.3350180102.

Golonka, J. \& Ford, D. 2000: Pangean (Late Carboniferous-Middle Jurassic) paleoenvironment and lithofacies. Palaeogeography, Palaeoclimatology, Palaeoecology 161, 1-34. doi: http://dx.doi. org/10.1016/S0031-0182(00)00115-2. 
Gradstein, F., Ogg, J. \& Smith, A. 2004: A geologic time scale 2004. Cambridge University Press, Cambridge, pp. 1-589.

Groves, J.R., Nassichuk, W.W., Lin, U. \& Pinard, S. 1994: Middle Carboniferous fusulinacean biostratigraphy, Northern Ellesmere Island (Sverdrup Basin, Canadian Arctic Archipelago). Geological Survey of Canada Bulletin 469, 1-55.

Halverson, G.P., Maloof, A.C. \& Hoffman, P.F. 2004: The Marinoan glaciation (Neoproterozoic) in northeast Svalbard. Basin Research 16, 297-324. doi: http://dx.doi.org/10.1111/j.1365-2117.2004.00234.x.

Haq, B.U. \& Schutter, S.R. 2008: A chronology of Paleozoic sealevel change. Science 322, 64-68. doi: http://dx.doi.org/10.1126/ science.1161648.

Harland, W.B. \& Geddes, I. 1997: Chapter 17 Carboniferous-Permian history of Svalbard. In Harland, W.B. (ed.): The Geology of Svalbard, The Geological Society of London Memoirs 17, pp. 310-339.

Harland, W.B. \& Kelly, S.R.A. 1997: Chapter 5 Eastern Svalbard Platform. In Harland, W.B. (ed.): The Geology of Svalbard, The Geological Society of London Memoirs 17, pp. 75-95.

Hjelle, A. \& Lauritzen, O. 1982: Geological map of Svalbard, 1:500,000, sheet 3G Spitsbergen, northern part. Norsk Polarinstitutt Skrifter 154C, pp. 1-15.

Holliday, D.W. 1966: Basal sediments of the Nordenskiöldbreen Formation (Middle Carboniferous) in the southwest coast of Brøggerhalvøya, Spitsbergen. Norsk Polarinstitutt Årbok 1966, 99-105.

Holliday, D.W. \& Cutbill, J.L. 1972: The Ebbadalen Formation (Carboniferous), Spitsbergen. Proceedings of the Yorkshire Geological Society 39, 1-32. doi: http://dx.doi.org/10.1144/pygs.39.1.1.

Hüneke, H., Joachimski, M., Buggisch, W. \& Lützner, H. 2001: Marine carbonate facies in response to climate and nutrient level: the Upper Carboniferous and Permian of Central Spitsbergen (Svalbard). Facies 45, 93-136. doi: http://dx.doi.org/10.1007/BF02668107.

Joachimski, M.M., von Bitter, P.H. \& Buggisch, W. 2006: Constraints on Pennsylvanian glacioeustatic sea-level changes using oxygen isotopes of conodont apatite. Geology 34, 277-280, http://dx.doi. org/10.1130/G22198.1.

Johannessen, E.P. \& Steel, R.J. 1992: Mid-Carboniferous extension and rift-infill sequences in the Billefjorden Trough, Svalbard. Norsk Geologisk Tidsskrift 72, 35-48.

Lauritzen, Ø. 1981: Investigations of Carboniferous and Permian sediments in Svalbard II. The Carboniferous and Permian stratigraphy of the Wahlenbergfjorden area, Nordaustlandet, Svalbard. Norsk Polarinstitutt Skrifter 176, 23-44.

Lauritzen, Ø. \& Worsley, D. 1975: Observations on the Upper Palaeozoic stratigraphy of the Ny Friesland area. Norsk Polarinstitutt Årbok 1973, 41-51.

Ludwig, P. 1989: Mittelkarbonische Beckenentwicklung auf der Broggerhalbinsel (Svalbard) - Sedimentologische Profilvergleiche und deren fazielle und tektonische Deutung. Polarforschung 59, 79-99.

Ludwig, P. 1990: Petrographie und Entwicklung von Calcrete in mittelkarbonen Alluvial Fans auf Spitzbergen (Norwegen). Neues Jahrbuch für Geologie und Paläontologie, Monatshefte 1990, 109-119.

Lønøy, A. 1995: A Mid-Carboniferous, carbonate-dominated platform, Central Spitsbergen. Norsk Geologisk Tidsskrift 75, 48-63.

Mamet, B. 1977: Foraminiferal zonation of the Lower Carboniferous: Methods and stratigraphic implications. In Kauffman, E.G. \& Hazel, J.E. (eds.): Concepts and methods of biostratigraphy, Hutchinson \& Ross, Dowden, pp. 445-462.

McCann, A.J. \& Dallmann, W.K. 1996: Reactivation history of the long-lived Billefjorden Fault Zone, in north central Spitsbergen, Svalbard. Geological Magazine 133, 63-84. doi: http://dx.doi. org/10.1017/S0016756800007251.

Miall, A. 1996: The geology of fluvial deposits: Sedimentary facies, basin analysis, and petroleum geology, Springer, Berlin, $582 \mathrm{pp}$.

Miloslavskij, M.J., Birjkov, A.S., Slenskij, S.N., Krasilscikov, A.A. \& Dallmann, W.K. 1998: Geological map Svalbard 1:100,000, sheet D8G Negribreen. Norsk Polarinstitutt Temakart 25, 32 pp.
Olaussen, S., Johansen, R., Johannessen, E.P. \& Knag, G.Ö. 1986: Karbon (Moskva) overgangslag pa Malte Brunfjellet, Ny Friesland Blokka, Spitsbergen. Unpublished report, Statoil.

Pickard, N.A.H., Eilertsen, F., Hanken, N.-M., Johansen, T.A., Lønøy, A., Nakrem, H.A., Nilsson, I., Samuelsberg, T.G. \& Somerville, I.D. 1996: Stratigraphic framework of Upper Carboniferous (Moscovian-Kasimovian) strata in Bünsow Land, central Spitsbergen: palaeogeographic implications. Norsk Geologisk Tidsskrift 76, 169-185.

Piepjohn, K., Brinkmann, L., Grewing, A. \& Kerp, H. 2000: New data on the age of the uppermost ORS and the lowermost post-ORS strata in Dickson Land (Spitsbergen) and implications for the age of the Svalbardian deformation. In Friend, P.F. \& Williams, B.P.J. (eds.): New perspectives on the Old Red Sandstone, The Geological Society of London Special Publications 180, pp. 603-609.

Pinard, S. \& Mamet, B. 1998: Taxonomie des petits foraminiferes du Carbonifere superieur-Permien inferieur du bassin de Sverdrup, Arctique canadian. Palaeontographica Canadiana 15, 1-253.

Ross, C.A. \& Ross, J.R.P. 1985: Late Paleozoic depositional sequences are synchronous and worldwide. Geology 13, 194-197. doi: http://dx.doi. org/10.1130/0091-7613(1985)13\%3C194:LPDSAS\%3E2.0.CO;2.

Samuelsberg, T. \& Pickard, N. 1999: Upper Carboniferous to Lower Permian transgressive-regressive sequences of central Spitsbergen, Arctic Norway. Geological Journal 34, 393-411. doi: http://dx.doi. org/10.1002/(SICI) 1099-1034(199911/12)34:4\%3C393::AIDGJ831\%3E3.0.CO;2-G.

Scheibner, C., Hartkopf-Fröder, C., Blomeier, D. \& Forke, H. 2012: The early Carboniferous in NE Spitsbergen (Svalbard) and a reevaluation of the Billefjorden Group. Zeitschrift der Deutschen Gesellschaft für Geowissenschaften 163, 293-308. doi: http://dx.doi. org/10.1127/1860-1804/2012/0163-0293.

Schutter, S.R. \& Heckel, P.H. 1985: Missourian (Early Late Pennsylvanian) climate in Midcontinent North America. International Journal of Coal Geology 5, 111-140. doi: http://dx.doi. org/10.1016/0166-5162(85)90011-4.

Soreghan, G.S. \& Giles, K.A. 1999: Amplitudes of Late Pennsylvanian glacioeustasy. Geology 27, 255-258. doi: http://dx.doi. org/10.1130/0091-7613(1999)027\%3C0255:AOLPG\%3E2.3.CO;2.

Steel, R.J. \& Worsley, D. 1984: Svalbard's post-Caledonian strata - an atlas of sedimentational patterns and palaeogeographic evolution. In Spencer, A.M., Johnsen, S.O., Mørk, A., Nysæther, E., Songstad, P. \& Spinnangr, Å. (eds.): Petroleum Geology of the North European Margin, Graham \& Trotman, London, pp. 109-135.

Stemmerik, L. 2000: Late Palaeozoic evolution of the North Atlantic margin of Pangea. Palaeogeography, Palaeoclimatology, Palaeoecology 161, 95-126. doi: http://dx.doi.org/10.1016/ S0031-0182(00)00119-X.

Stemmerik, L. \& Worsley, D. 1989: Late Palaeozoic sequence correlations, North Greenland, Svalbard and the Barents Shelf. In Collinsen, J.D. (ed.): Correlation in Hydrocarbon Exploration, Graham \& Trotman, London, pp. 99-111.

Stemmerik, L. \& Worsley, D. 2000: Upper Carboniferous cyclic shelf deposits, Kapp Kare Formation, Bjørnøya, Svalbard: response to high frequency, high amplitude sea level fluctuations and local tectonism. Polar Research 19, 227-249. doi: http://dx.doi. org/10.1111/j.1751-8369.2000.tb00346.x.

Stemmerik, L. \& Worsley, D. 2005: 30 years on - Arctic Upper Palaeozoic stratigraphy, depositional evolution and hydrocarbon prospectivity. Norwegian Journal of Geology 85, 151-168.

Stemmerik, L., Elvebakk, G., Nilsson, I. \& Olaussen, S. 1998: Comparison of upper Bashkirian-upper Moscovian high frequency cycles between Bjørnøya and the Loppa High, western Barents sea. In Gradstein, F.M., Sandvik, K.O. \& Milton, N.J. (eds.): Sequence Stratigraphy - Concepts and applications, Elsevier, Amsterdam, pp. 215-227.

Tebenkov, A.M., Ohta, Y., Balsov, J.A. \& Sirotkin, A.N. 1996: Newtontoppen granitoid rocks, their geology, chemistry and $\mathrm{Rb}-\mathrm{Sr}$ age. 
Polar Research 15, 67-80. doi: http://dx.doi.org/10.3402/polar. v15i1.6637.

Theriault, P. \& Desrochers, A. 1993: Carboniferous calcretes in the Canadian Arctic. Sedimentology 40, 449-465. doi: http://dx.doi. org/10.1111/j.1365-3091.1993.tb01345.x.

West, R.R., Archer, A.W. \& Miller, K.B. 1997: The role of climate in stratigraphic patterns exhibited by late Palaeozoic rocks exposed in Kansas. Palaeogeography, Palaeoclimatology, Palaeoecology 128, 1-16. doi: http://dx.doi.org/10.1016/S0031-0182(97)81127-3.

West, R.R., Miller, K.B. \& Watney, W.L. 2010. The Permian system in Kansas. Kansas Geological Survey Bulletin 257, 1-82.

Winsnes, T.S. 1966: Observations on the Carboniferous and Permian rocks of Vestspitsbergen. Norsk Polarinstitutt Årbok 1964, 7-29.

Worsley, D. 2008: The post-Caledonian development of Svalbard and the western Barents Sea. Polar Research 27, 298-317. doi: http:// dx.doi.org/10.3402/polar.v27i3.6197.

Worsley, D., Aga, O.J., Dalland, A., Elverhøi, A. \& Thon, A. 1986: The Geological History of Svalbard, evolution of an arctic archipelago. Statoil, Stavanger, $120 \mathrm{pp}$.

Wright, V.P. 1994: Paleosols in shallow marine carbonate sequences. Earth-Science Reviews 35, 367-395. doi: http://dx.doi.org/ 10.1016/0012-8252(94)90002-7.

Wright, V.P. 2007: Calcrete. In Nash, D.J. \& McLaren, S.J. (eds.): Geochemical sediments and landscapes, Blackwell, Oxford, pp. $10-45$. 